\title{
Empowerment for individual agency: an analysis of international organizations' curriculum recommendations
}

\section{Mike Zapp}

To cite this article: Mike Zapp (2019): Empowerment for individual agency: an analysis of international organizations' curriculum recommendations, Globalisation, Societies and Education, DOI: $10.1080 / 14767724.2019 .1577717$

To link to this article: https://doi.org/10.1080/14767724.2019.1577717

Published online: 18 Feb 2019.

2 Submit your article to this journal $2 \pi$

View Crossmark data \lceil 


\title{
Empowerment for individual agency: an analysis of international organizations' curriculum recommendations
}

\author{
Mike Zapp ${ }^{\mathrm{a}, \mathrm{b}}$
}

${ }^{a}$ Institute of Education and Society, University of Luxembourg, Esch-sur-Alzette, Luxembourg; ${ }^{b}$ Graduate School of Education, Stanford University, Stanford, USA

\begin{abstract}
Much recent research stresses the increasing relevance of international organisations (IOs) for national education policymaking. Yet, IOs' curriculum recommendations have remained largely out of scope, although they provide a forceful example of 'soft' governance. Based on a content analysis of 83 documents from 42 inter/-nongovernmental, global and regional organisations involved in international education networks between 1990 and 2015, this paper identifies an expansive field of IOs directing growing attention to such curricular issues as student needs, educational goals and content, as well as issues of teaching and learning. In line with much cross-national curriculum research, analysis provides evidence for the trend towards a global curriculum model stressing empowerment, individual agency and psychosocial development. The article argues that the strong focus on human capabilities and human capital in IOs' curriculum policies reflects wider cultural transformations in contemporary world society. The article concludes by arguing for an expanded analytical scope of IOs' educational work and a reconsideration of causal explanations in curriculum theories.
\end{abstract}

\section{ARTICLE HISTORY}

Received 16 May 2018

Accepted 10 December 2018

\section{KEYWORDS}

International organisations;

curriculum; empowerment; individual agency;

psychosocial development

\section{Introduction}

International organisations (IOs) - intergovernmental and non-governmental alike - have grown dramatically in number and kind during the second half of the twentieth century. This holds true for both IOs in general and those specifically dealing with education, reflecting the growing importance ascribed to education from the 1950s to the present day. As an important starting point, the Education for All Initiative (EFA), has, since 1990, created a vast network of governments, regional and global international intergovernmental (IGOs) and nongovernmental (INGOs) organisations (Chabbott 2003; Zapp and Dahmen 2017).

The goals of EFA, together with the Millennium Development Goals (MDGs), call for the expansion of quality educational and learning opportunities at all levels. With concern about the performance of their systems, nation-states around the world have, more often than not led by IOs, started to introduce (now routine and sometimes mandatory) large-scale assessments to measure competencebased educational and vocational output at virtually all levels (Heyneman and Lykins 2008).

This shift from input governance and structural educational expansion through legislation and funding to output measurement and achievement testing has been much discussed in the literature and will be presented in Part Two of the article (Benavot and Meyer 2013; Gorur 2014). The

CONTACT Mike Zapp @ mike.zapp@uni.lu Institute of Education and Society, University of Luxembourg, 11, Porte des Sciences, L-4366 Esch-sur-Alzette, Luxembourg

() 2019 Informa UK Limited, trading as Taylor \& Francis Group 
particular role IOs play in this 'metrological mood' (Power 2004, 766) in education has led to a change in scholarly thinking about IOs from regulative or coercive governance to 'softer' normative instruments (Baker and Wiseman 2005; Mundy and Ghali 2009).

While both rationales (expansion and measurement) continue to play an important role in IOs' educational work, I suggest that the premium on quality and achievement, has led to a new phase in educational thinking at the IO level. This recent phase has been marked by a pronounced focus on curricular goals, content as well as teaching and learning processes.

Despite the considerable theoretical and empirical literatures on emerging global governance structures in education, the potential role of IOs in cross-national curriculum change has remained largely out of scope or rather implicit. This is surprising since much institutionalist curriculum research, for example, attributes great general causal influence to IOs as these promote standardised educational models worldwide (Bromley, Meyer and, Ramirez 2011). Moreover, single country case studies see a direct link between OECD work in education, for example, and national curricular reform (Zapp and Powell 2016). The main findings of this body of research are discussed in Part Three.

This paper argues that the study of IOs represents a considerable blind spot in curriculum research, which in general lacks strong empirical foundation (Young 2013; Baker 2015). It is based on the assumption that IOs matter in national curriculum policies and that it is imperative to examine curricular elements at the IO-level. The article will show that, since the mid-1990s, a considerable and growing number of IOs has started to develop specific curricular recommendations. Based on a comprehensive sample of 83 documents from 42 global, regional and bilateral IGOs and INGOs involved in the EFA and MDG networks as well as the Global Campaign for Education (GCE), this paper identifies a surprisingly elaborated curricular 'thinking' in the global educational discourse across all types of IOs. Their curricular work often includes such core features of traditional state-based curriculum-making as subjects and descriptors, content and categories of students at various levels as well as the social and educational rationales underpinning the curriculum (Westbury 2016).

Part Five describes these curricular recommendations including issues like types of learners, learning goals, instructional content along with (cross-curricular) skills, competences and psychosocial capacities as well as teaching and learning methods.

These recommendations, like most recommendations produced by IOs in global education policy, have no legally-binding status. They are neither hard nor soft law, but rationalised models of reform and progress (Meyer et al. 1997; Chabbott 2003). They are not targeted towards specific countries, education systems or groups of students and learners. They are highly theorised and de-contextualized stressing human rights, global identity, human capabilities and capital. Individual empowerment and psychosocial development emerge as the central goals in these prescriptions. Their mere cognitive status notwithstanding, previous research has shown that cross-national policy change in education does not require hard instruments (see Baker 2015 for a review).

In Part Six, the paper discusses these findings in the context of previous comparative research on curricula change. The strong emphasises in these recommendations on individual agency and global identity will be given particular attention. The article concludes by arguing for complementing the view of IOs in global educational governance with more detailed accounts of the education models promoted, including curriculum models.

\section{International organisations and education}

In recent years, scholarship on education has systematically introduced IOs into the analysis of educational governance and policy-making. Important macro-approaches stressing the role of IOs in globalising education include Dale's (2005) pluri-scalar governance of education in the EU where governance activities such as funding, ownership, provision and regulation are reshuffled along subnational, national and supranational levels. Mundy (2007) proposes educational multilateralism 
describing IOs as 'a new venue for political contests over shared norms and institutions' (Mundy $2007,20)$. In a similar vein, Parreira do Amaral (2010) sees an international regime rising in education with governmental and non-governmental, national and international organisations institutionalising education globally.

From an institutionalist perspective, Chabbott (2003) examined the role of IOs in the EFA initiative where she finds a global organizational field of educational development. Her analysis includes various organisational types, their networks and governance mechanisms. Chabbott (2003) argues that knowledge production matters more than regulative instruments in explaining the diffusion of education models among IOs themselves and countries. Here, mimetic processes and the role of professionals in spreading common development models, common organisational principles and common action frameworks among organisations are causal factors contributing to worldwide isomorphism in educational structure and content.

Moreover, researchers from neighbouring fields such as comparative and international (development) education interested in the movement of educational policies have begun to examine the roles of certain international actors and their governance instruments. This strand of research is mainly interested in policy diffusion (e.g., imposition, learning, lending, borrowing, transfer and so forth) (e.g., Jakobi 2012). IOs have traditionally been treated as 'hard' players that regulate, fund and impose education policies (Scherrer 2007; Mundy and Verger 2015). Conditionality policies imposed by the World Bank and International Monetary Fund were (and still are) salient examples of such coercive policy influence. Similarly, the World Trade Organization's General Agreement on Trade in Services has legally-binding authority (Komljenovic and Robertson 2016). More recent contributions stress, however, IOs' normative influence as 'teachers of norms' (Finnemore 1993) or 'knowledge brokers' (Jakobi 2006). Here, governance is carried out, for example, through coordination, comparison or agenda setting.

In the context of the EU, Martens (2007), for instance, analyses the Open Method of Coordination as a soft mechanism serving to monitor member states' compliance with European definitions of best practice. Similarly, Kallo $(2006,282)$ analyses OECD soft governance in terms of 'strategic consulting, peer pressure, public studies and direct and indirect agenda-setting'. Other examples include the global diffusion of formal science policy by UNESCO (Finnemore 1993), the successful promotion of national qualification frameworks by the EU and OECD (Jakobi 2009), the controversial role of INGOs in educational decentralisation (Rappleye 2011) or the WB's growing role as an educational 'knowledge bank' (Zapp 2017b).

Related to the topic of this paper, Zapp and Powell (2016) traced the effect of OECD's large-scale assessments like TIMSS and PISA on German educational research practices and curriculum standards reflecting a general trend towards output control (Hopmann 2003). In her analysis of nationstates' conformity to UNESCO principles of non-discrimination in education, McNeely (1995) found strong commitment and argues that IOs play an important role in defining and transmitting global educational goals.

Such approaches are highly useful in providing a fresh perspective on how to rethink educational planning and organisation in a globalised world, acknowledging the critical importance IOs have gained in the past two decades for national education policymaking (Mundy and Ghali 2009). The novel understanding of IOs as 'theorists' or 'epistemic actors' that provide rationalised and standardised models of educational reform worldwide based on the legitimacy and authority of scientific knowledge is particularly helpful in trying to make sense of cross-national isomorphic change in educational structure, policy and content (see Meyer et al. 1997 and Baker 2015 for reviews).

However, two blind spots remain. First, most research on globalised education is marked by an excessive interest in the 'Big Five', that is, UNESCO, WB, OECD, EU and (albeit less) ILO (see Zapp and Dahmen 2017 for a review). Focusing on the 'Big Five' has its reasons. These organisations raise most of the funds, possess most of the expertise, pursue the most thorough strategies and might exert most of the influence in the field. Yet, more recent contributions have shown that the organisational field in global education has grown considerably since the start of the EFA campaign, now including 
a growing number of burgeoning intergovernmental, nongovernmental, global and regional international organisations alike (Parreira do Amaral 2010).

Secondly, the impact of IOs on national education policy is usually measured ex post. In much of the research interested in the role of IOs, norms and their diffusion or transfer are assessed in terms of an adopted law or programme. Such an approximate variable is often the closest we can get to operationalise 'flows' from IOs to nation-states. Where early childhood education (ECE) laws are enacted (Jakobi 2006), adult education programmes are renamed as lifelong learning programmes (Schemmann 2007) or higher education reforms initiated (Schuetze and Slowey 2000), authors speak of successful diffusion. When such action is absent, countries are described as laggards' (Jakobi 2009, 145). I argue that a prior analytical step would consist in examining the construction of specific educational models and concepts at its source, i.e. IOs themselves. Much comparative (sociology of) education and scholarship lacks a thorough investigation of the content of educational models and recommendations at the IO level, particularly with regard to emerging curricular prescriptions.

Do IOs have explicit and elaborated recommendations concerning the goals, content, teaching and learning processes for national curriculum reform? Do these IOs increasingly include other organisations than those usually investigated, i.e. the 'Big Five' (UNESCO, OECD, WB, EU, ILO), reflecting the wider interest in education at the international level since the 1990s?

\section{Findings from cross-national curriculum research}

Traditionally, curricular research has focused on national factors that determine the goals and content of education. This line of explanation still prevails in the literature despite acknowledging the globalised frame of national education policymaking (see for example Cummings 2003). The state-centric perspective also informs the main theoretical assumptions in the field such as class and stratification theory and cohesion theory (see Rosenmund 2000, 2006; Young 2013 for reviews). Such statist views of curricula as national 'arenas' or 'cultural sieves' are challenged by a growing body of cross-national curriculum research that provides evidence for increasing isomorphism across countries and over time regardless of national cultural, social, political and economic factors. I briefly review the main findings from this body of research.

Benavot and Riddle (1988) show worldwide standardisation in the form of the 6-3-3 years model advanced by UNESCO. In an analysis covering between 31 and 82 countries for the period 19201986, Benavot et al. (1991) found that a core of liberal subjects had emerged, dominating curricula in highly diverse countries across the world (including very poor and very rich countries). This 'world educational standardization' (Benavot et al. 1991, 91) includes instruction in (official) language, mathematics, natural science, liberal or general social sciences, the arts, and physical education. For higher education, Frank and Gabler (2006) chart the rise of the social sciences and the decline of the humanities over the twentieth century.

Some analyses focus on particular school subjects. For mathematics and the sciences, for instance, Kamens and Benavot (1991) show an increasing emphasis worldwide during the twentieth century, with national characteristics being weak predictors of variations in official instructional time devoted to both school subjects. Similarly, Cha and Ham (2011) trace the cross-national institutionalisation of English as a school subject beyond country-level variables. They interpret this trend as reflecting expansive conceptions of supranational citizenship.

In the same vein, the general trend towards the American 'social studies' model and a de-territorialised and de-nationalised curriculum stressing global humanity and the general ecosystem have been backed by Wong (1991) and Rauner (1998). This new curriculum model depicts the individual as being embedded in a rationalised cosmos rather than in a religious order, national society or economy.

Other longitudinal analyses document a shift towards greater student-centeredness, environmentalism, diversity and human rights in textbooks over the second half of the twentieth century 
(Bromley 2014). Further, the increasing institutionalisation of human rights at various educational levels further support the claim of a world cultural socialisation of the individual in the more recent period (Bromley and Suarez 2012).

Pedagogically, a cross-national shift away from canonical learning towards active, studentcentred learning in science was documented in McEneaney (1998) and Bromley, Meyer, and Ramirez (2011). Here, self-directed and more individualised learning processes instead of 'sacred knowledge' gain more importance in recent decades (Young 2013, 102).

In an important contribution, Rosenmund $(2003 ; 2006)$ analysed the rationales for curriculum change and curriculum content in a sample of 100 countries during the 1990s through national reports submitted to UNESCO. Rationales as expressed in national discourses now routinely refer to external factors in justifying curriculum adaptation. He further finds a growing emphasis on self-directed learning and a 'far more cosmopolitan view of the individual' (Rosenmund 2006, 3).

In one of the few studies that look at the link between curriculum reform and international organisations, Zapp and Powell (2016) traces the impact of OECD's PISA study on German curriculum policy. PISA and the OECD's general focus on competence measurement shifted the focus from curriculum-based learning (and soft skills) or 'inert knowledge' to cognitive skills in the guise of scientific literacy and applied learning. This new focus provided the blueprint for important curricular reforms and the establishment of national education standards, especially in mathematics and natural sciences, despite highly decentralised educational federalism.

These lines of research suggest that curricula worldwide seem to converge towards a common set of subjects, goals and practices stressing the autonomous and empowered individual situated in a 'post-national' world society.

Based on the growing evidence for increasing isomorphism in curricular developments with regard to educational actors, goals, content as well as teaching and learning, we may formulate the following guiding questions. Is IOs' curriculum thinking informed by similar themes and rationales as those found in cross-national curriculum research? Do curriculum recommendations vary by IOs' type or location reflecting more specific agendas and regional/ local needs? The following section presents the sample of IOs and the analytical framework used in the study.

\section{Methodology}

\subsection{Sample and data}

The sample of international organisations consists of organisations actively involved in major educational campaigns and initiatives. These include Education for All (EFA), the education partners in the Millennium Development Goals (MDG) network and the Global Campaign for Education (GCE). ${ }^{1}$ The Education for All movement started in the 1990s and was formally adopted by the Dakar Framework in 2000. Led by UNESCO, EFA brings together a wide range of partners including individual 'ambassadors' and government agencies, public-private partnerships as well as INGOs and IGOs (Chabbott 2003). It has a semi-formal status as it does not have a permanent secretariat. It is organised within the UNESCO structures by a steering committee, holds regular meetings and publishes its Global Monitoring (now Global Education Monitoring) Report. By contrast, the Millennium Development Goals network is a loose consortium of mainly UN-affiliated agencies and regional commissions. It emerged from the Millennium Declaration in 2000 (UN 2016). Finally, the Global Campaign for Education, founded in 1999, brings together a dozen INGOs as well as scores of local NGOs from over 80 countries. Similar to EFA, GCE is organised as a member coalition holding regular meetings, represented by a board and publishing regular reports (GCE 2016).

In these three initiatives, we find most of the major regional and global organisations such as UNESCO, WB, UNICEF, ILO, OECD, African Union and European Union, but also many INGOs such as Education International and ActionAid International. Also included in these 
networks are internationally-oriented bilateral development agencies like Agence Française de Développement, USAID or EuropeAid.

I acknowledge some typological blur especially from a legal perspective on internatiponal organisations (see Klabbers 2018 for a review). By common definition and usage, all these types (including bilateral agencies) are, however, seen as IOs (see the authoritative Yearbook of International Organizations published by the Union of International Associations which has been active in the research field since 1907). They are international in scope, mission and operation and, except the bilateral agencies, in membership (UIA 2017).

The final sample contains 42 IOs and considerably extends the dominant focus on the 'Big Five'. Selecting major initiatives as a sampling strategy might reflect more substantial similarity in discourse than a 'randomized' IO population. However, such initiatives are the very key in diffusing major educational ideas, principles, standards, innovations and curricular design as shown in global educational governance scholarship (Chabbott 2003; Zapp and Dahmen 2017). Investigating the content being diffused here, is, therefore, the starting point of analysis.

The final sample of IOs was determined by the on-line availability of relevant documents. Document sampling was done based on relevance criteria. Documents were included that made an explicit reference to at least three of the analytical core categories of curriculum research (see below) to ensure an elaborated curriculum 'thinking' (as opposed to incidental reference) is captured in the analysis. By curriculum 'thinking', I broadly refer to a purposive and systematic reflection on curricular function, design and implementation. Obviously, IOs' documents under study here are not the result of efforts and negotiations, as in national contexts, between ministries, boards and departments of education and, sometimes, jurisdictions, legislatures and their committees (Westbury 2016). As widely circulating documents, they represent, however, deliberate attempts to engage with national curricular work.

Included in the sample are so-called flagship publications and other official documents of high importance, which were made publicly available by IOs (e.g., UNESCO's Global Monitoring Report, papers on strategy and policy, executive summaries). Table A1 in the Appendix provides a description of the organisations and documents analysed.

The Education for All year, 1990, is the starting point for document sampling as it marks the beginning of heightened and concerted interest in this issue among the international organisational community (Chabbott 2003). The search process ends with the World Education Forum in 2015.

\subsection{Analysis}

Analysis was done using four theoretically derived overarching core categories. These include general heuristics used in much (cross-national) curriculum research (see above). They comprise the target groups and education level (Who?), the goals of educational intervention (What for?), the curriculum content (What?) and the teaching and learning processes (How?). The target groups refer to the type of students and learners specified by their age, formal or informal setting or any other characteristic such as gender, geographical location or social position. This category also comprises the levels stated in the documents from early childhood education to lifelong learning. Goals refer to the broader rationales of education (as opposed to outcomes) as defined for learners, students and the wider context (education system and society). Curricular content refers to school subjects such as natural sciences, languages or history and the competences and skills stated as the basis of curriculum planning and design. Teaching and learning encompasses the suggested interaction pattern between learners and teachers in the learning process and classroom including the specific pedagogical approach.

For further refinement of categories, the qualitative content analysis tools of constant comparison, (open, axial, selective) coding, memo writing and integration of concepts and categories were applied supported by the software MAXQDA (Corbin and Strauss 2008). More precisely, while creating overarching categories, I found, for example, that teaching and learning can be specified as a particular understanding of the role of students, teachers and schools. Or, while coding documents for 
educational content, I identified several overlapping concepts formulated by IOs. These included skills, capacities, key competences or cross-curriculum competences. Whenever substantively necessary, I created new conceptual sub-categories to capture the complexity of IOs' recommendations and to identify novel elements. Core categories were, thus, substantially bolstered with lower-level sub-categories and concepts that helped to further integrate data across the 42 IO cases and to add more particular analytical thrust to each IO. In a multi-month coding process, a multitude of conceptual categories was created (see Table A2 for the complete coding system). In order to guarantee inter-coder reliability, samples were analysed by at least two members of the research project team (reliability at $89 \%$ ). ${ }^{2}$ For descriptive purpose, quantitative indicators are given for the number of IOs referring to the key category in curricular recommendation. I now turn to the findings of my analysis, structured according to my analytical core categories.

\section{Findings}

In general, IOs show increasing interest in curricular questions over time. Figure 1 reports on the appearance of the first document containing at least three of the four core categories. While references to curricular design are rare until the millennium, there is a considerable increase since then and especially after 2005. It is remarkable that organisations although only recently founded immediately join the international curricular discourse (e.g., African Union). Given the conservative document sampling (i.e., containing at least three core categories), some earlier documents, especially by UN agencies and the EU, are omitted from this analysis. Timing does not vary considerably between types of IOs although INGOs are slightly slower in joining the curricular discourse.

Along with the general increase in organisational statements, references to specific key categories accumulate over time. Table 1 compares an early period from the sample (1990-2003) with a more recent sample of organisational documents (2003-2015) as well as differences between various IO types and their geographic scope (defined by membership). Overall, references to these key elements increase for all core categories across type and geography of IOs. Between-group differences by type of IO are surprisingly small overall. Notable differences exist only for level specifications and teaching and learning recommendations, although small sub-sample numbers make strong comparisons difficult. Some notable area differences exist between the importance given to ICT, with organisations representing the Southern hemisphere referring more frequently to the idea than Northern organisations.

These key elements describe the empowered individual learner (not the student) in secondary education. They specify human rights as a key component of the curriculum content along with a wide array of key skills or meta-competences and a reference to a particular set of behavioural or attitudinal traits, most notably creativity. Specific teaching and learning recommendations include the use of ICT and a re-definition of the role of teachers. We now turn to these findings and other, less salient categories (see, Appendix Table A2) in more detail.

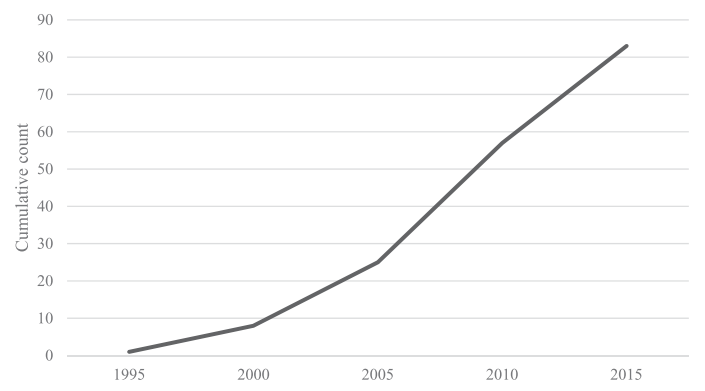

Figure 1. Increase in $10 s^{\prime}$ documents containing curricular recommendations $(N=83)$. 
$8-$ M. ZAPP

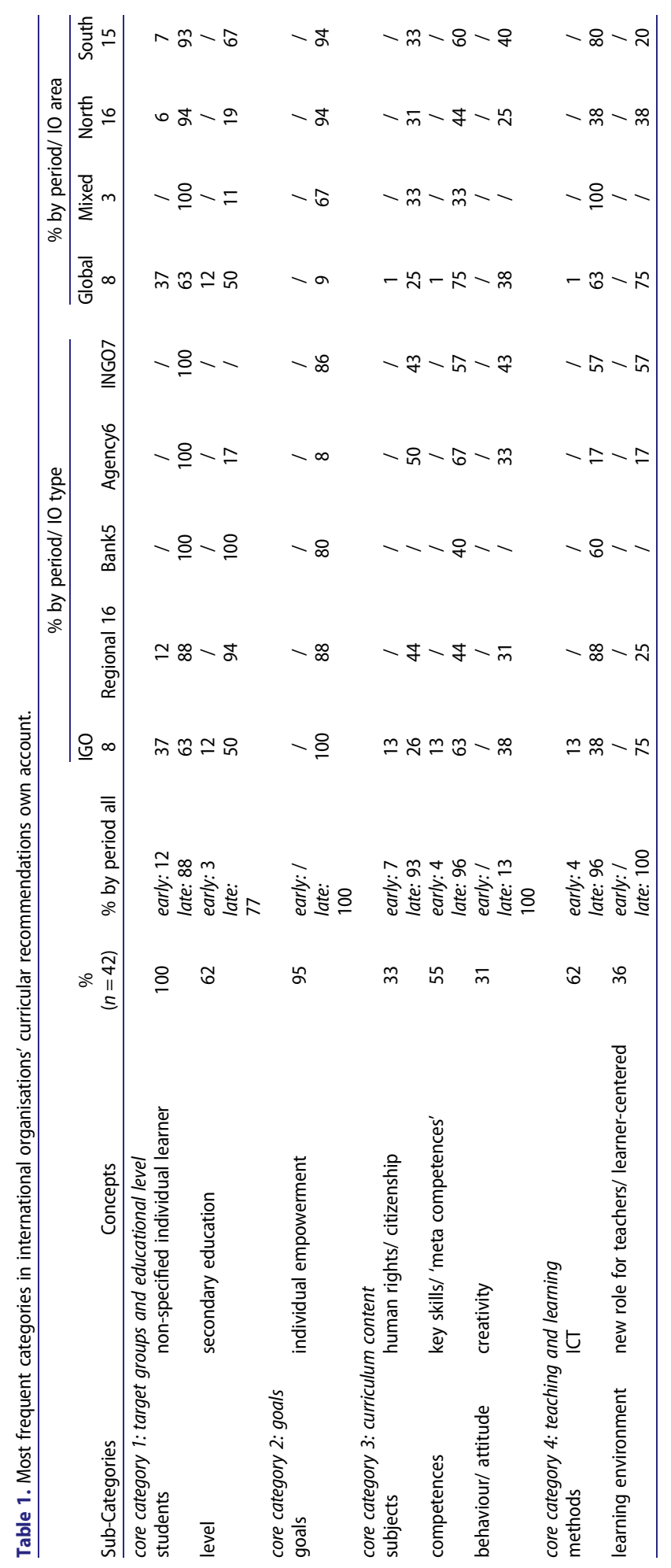




\subsection{Students and levels}

Paradoxically, organisations in the sample direct their recommendations to such a myriad of learner populations that it does not seem plausible to differentiate between different types of learners and related curricular recommendations. As a general finding, the vague depictions of an educational system or model contrast with the detailed picture of the individual who is at the core of virtually all of the contributions analysed. This finding will be discussed further in the following section.

The most obvious criterion that organisations use to select populations is educational. Educational intervention is for both those with little education and those at the upper end of the educational ladder. Educational intervention is targeted towards the illiterate, out-of-school children, dropouts or early school leavers (OAS 2001, 36; AFD 2006, 7; JICA 2007, 19; PIF 2007, 12; AFDB 2007b, 16; SAARC 2010, 37). Calls for more education for upper secondary students, higher education students, $\mathrm{PhD}$ students, non-traditional students and the non-skilled mostly (but not exclusively) emanate from richer countries (CoEDB 2006, 8; EU 2012, 4). In short, educational expansion is for both 'the knowledge-haves and knowledge have-nots' (OECD 2004a, 2), for both the 'educational poor and educational rich' (UNESCO 2009, 43 f.).

There are also broadly defined groups based on socioeconomic criteria including the unemployed, the underemployed, the informally employed (often self-employed or rural workers) and the formally employed. While the first three groups are expected to increase their employability through education/ lifelong learning, the latter group comprises highly diverse traditional sector workers, rural workers, manual and non-manual workers and employees in small and medium-size enterprises. They all have 'to update skills' (EU 2000, 11) in order to 'keep pace with the complexity and dynamics of economic and social development' (GIZ 2011a, 1).

Neither is there a clear pattern regarding age groups in education documents with references ranging from the unborn (UNESCO 2010, 43; WB 2013, 175) to older workers and the retired (EU 2001, 13; WB 2003b, 58). Education is thought to be apt to address both 'youth bulges' (WB 2013, 207) and the 'aging of our populations' (CoEDB 2006, 8). More often than not educational levels are not explicitly stated as will be shown below in the context of specific curriculum designs. Instead, wherever the level is specified, organisations either stress educational intervention as early as possible (a legacy of EFA) or as a lifelong, continuous process (a legacy of the global discourse on lifelong learning in the early 2000s). It is, therefore, little surprising that education and learning starts before birth as touched on above. Informed by findings from neurological science, IOs place the beginning of learning ever more back to the 'period from about three months before birth [...]' as this phase ' $[\ldots]$ is critical to the formation of neural pathways, while the first three years are marked by rapid development of language and memory' (UNESCO 2010a:43). Such a consensus is, above all, nurtured by the assumption that 'human capital is cumulative', with particular importance of the 'first 1000 days' when 'ensuring adequate nutrition, health, and cognitive stimulation through a nurturing environment [...] raises returns to later child investments significantly' (WB 2013:86-87).

If there is any pattern at all in target groups, it might be those who are marginalised in some way. This marginalisation can be based on gender or location, ethnic and religious background, migration status or disability, conflict-ridden or disaster areas and diseases. These 'most in need' (CAN 2004), 'most vulnerable' (e.g., ECOSOC 2011, 24), 'under-represented' (e.g., DFID 2011c, 11), 'unreached' (e.g., SAARC 2010, 10) and 'underserved' (e.g., IMF 2012, 185) are, by implication, those with the least access to education and therefore receive more attention.

\subsection{Educational goals}

There is a great emphasis on what education is meant to bring about in an individual's life. To make the centrality of the individual in IOs' arguments more comprehensible, I used a number of (partly- 
overlapping) concepts. Although there may well be additional collective goals associated with education, such as economic growth or social cohesion, judged by quantity and quality, the goals linked to the individual learner far outweigh the collective ones.

Education means, above all, empowerment. Empowerment is among the most frequently-mentioned concepts in the whole sample. Economic empowerment or employability are important goals in education documents, and can apply to children, young people, women, students, farmers or, simply, learners. However, economic empowerment is just one specification of the otherwise very general idea that people take 'ownership and control of their own endeavours and destinies' (WHO 2007, 38). It can take also take the form of emancipation, although this latter term is rare and usually applied to women (EU 1995, 2; JICA 2010,46) or disadvantaged social groups (DFID 2004, 1).

Calls for empowerment are always linked to a strong belief in individual capacities and potential for personal development. This is true for children, where ECE is the first step of 'the continuum of lifelong learning for children to maximize their potential as individuals and as members of a productive society' (WB 2003a, 56); but also in the guise of vocational education, which 'has much to contribute to holistic human development' (ECOSOC 2011, 82).

It also holds for migrants (EU 2011, 123) and people with disabilities:

The development by persons with disabilities of their personality, talents and creativity, as well as their mental and physical abilities, to their fullest potential; [... in order] to participate effectively in a free society. (DFID 2011b, 20)

It eventually becomes clear that this concept applies to all people:

'Education and skills development underpin any strategy of human development and productivity as it is through education that the necessary skills, knowledge and aptitudes are acquired, and the creative abilities of individuals released, to open the way to a better life and society. (IMF 2012, 74)

Sometimes 'key skills' in the curriculum (see below) simply become 'personal development tools' (UNESCO 2000, 66). The World Bank $(2011,13)$ feels obliged to stress that

The development benefits of education extend well beyond work productivity and growth to include better health, reduced fertility, and enhanced ability to adopt new technologies and/or cope with economic shocks, more civic participation, and even more environmentally friendly behavior. (see also AFD 2015, 1)

It is within this often vague realm of economic effects on the one hand and emotional, physical and mental effects on the other that education turns for most organisations into the key element of their strategies. Education is here understood as the ultimate means to reach 'personal fulfilment, wellbeing, and happiness' (EU 2011, 22). Such statements can even become transcendental:

After all, Happiness in this world and in the Hereafter can be attained when right knowledge is accompanied by ethical action. (IDB 2006, 24)

In line with such general calls for empowerment and individual development, and the broad curriculum that targets individual personality and psychosocial capacities more than knowledge, numerous organisations go on to paint the strikingly well-contoured profile of a prototype of the individual autonomous learner. The empowerment of the learner here means 'to master the tools of knowledge and build an all-able personality' (LAS 2008, 32) and 'to make informed career decisions' (OECS 2007, 24) encouraging them 'to take their professional future in their own hands' (AFD 2006, 19).

According to UNESCO $(1996,21)$, the millennium requires a change in thinking in general:

In the twenty-first century everyone will need to exercise greater independence and judgement combined with a stronger sense of personal responsibility for the attainment of common goals.

In general, organisations place a great emphasis on individuals' 'mentality' by establishing a firm link between competences, skills, motivation, attitudes and behaviour as, for instance, with entrepreneurship: 
Specific psychological traits are associated with entrepreneurship, such as a personal need for achievement, a belief in the effect of personal effort on outcomes, self-confidence, and a positive attitude toward risk. (WB 2013, 114)

Entrepreneurship is likely one example of such 'psychologicalisation', but it is by no means the only one. What emerges here is an impressive list of characteristics or personality traits to which organisations from all areas and of all types have something to contribute. I will explore this argument in more detail in the following section.

\subsection{Curriculum content}

Various actors representing different regions agree on the importance of a certain set of subjects. Frequent references include the sciences, social studies, languages and human rights. The latter spans a wide array of more concrete topics, ranging from civic education, gender education, peace education and intercultural competence to moral reasoning and action. These subject-related curricula are often complemented by basic or life skills (see Table A2). More often than not, curriculum reforms are considered desirable by actors without specifying the educational level. OECD (1996), for instance, favours as early as possible and UNESCO (2001) stresses the importance of such holistic curricula in TVET.

At first glance, curriculum recommendations seem to reflect regional differences in that basic skills (e.g., literacy, numeracy, health education) are more strongly pronounced in the development context. However, where basic skills and life skills are compared with the so-called key competences or meta-competences, these differences disappear and a standardised 'core curriculum' emerges:

Life skills can be described as 'a group of psychosocial competences and interpersonal skills that help people make informed decisions, solve problems, think critically and creatively, communicate effectively, build healthy relationships, empathise with others and cope with and manage their lives in a healthy and productive manner.' (UNESCO 2007b, 56)

Compared to the relatively few explicit references to specific school subjects, the broad consensus on the importance of so-called key competences is striking. Many organisations with diverse missions and from diverse geographical areas emphasise a (often very loosely-defined) battery of meta-competences, meta-cognitive skills or transversal skills. In order to illustrate the complexity and detailed degree of IOs' discussion, Table 2 provides an example for three major IOs. Early on, the OECD (1996, 103-121) alone had identified nine cross-curriculum competences, the EU (2007b) proposes eight and UNESCO exceeds both by far.

The EU still remains somewhat subject-based in its curricular portfolio, proposing linguistic, scientific and digital competences reflecting the main findings from cross-national curriculum research (Benavot et al. 1991). In contrast, both the OECD and (even more strongly) UNESCO stress transversal skills or competences. It is clear that these 'competences' go beyond technical skills; they also include knowledge, attitudes, dispositions, values and emotional aspects. UNESCO (2008) proposes the most complex picture, where ideas of oneness and unity add particular spiritual and identity aspects.

Following the dizzying array of suggestions, this list can only be selective. I found it necessary to use numerous conceptual categories to capture the bundle of cognitive, social, ethical/moral, behavioural, communicative and emotional 'competences' (Table 2). The terminology turns out to be difficult to describe in its full complexity as the notion of 'competences' has become a catch-all term for what might otherwise be called qualities, traits, dispositions, values, attitudes, capacities, skills and abilities. Taken together, OECD (1996), OECS (2002, 8), SAARC (2007, 21), EU (2007b) and UNESCO (2008) propose almost 40 different 'competence areas', even excluding vocational competences.

The centrality of core competences sheds light on the learner personality more than on actual subjects or system reforms, they are formulated on the basis of a strong individualistic 
Table 2. Examples for curriculum content proposed by OECD (1996), EU (2007b) and UNESCO (2008).

\begin{tabular}{lll}
\hline OECD & \multicolumn{1}{c}{ EU } & \multicolumn{1}{c}{ UNESCO } \\
\hline - problem-solving & - communication in the mother tongue & - inter-personal competences \\
- critical thinking & - communication in foreign languages & - self-confidence \\
- communication & - mathematical competence and basic & - self-esteem \\
- democratic values & competences in science and technology & - self-image \\
- understanding of political processes & - digital competence & - self-reflection \\
- self-perception & - learning to learn & - self-motivation \\
- self-confidence & - social and civic competences & - learning to listen and question \\
- learning to learn & - sense of initiative and entrepreneurship & - constructive and critical thinking \\
- information retrieval skills & - cultural awareness and expression & - communicative competences \\
& & - self-directed learning \\
& & - basic literacy \\
& & - sense of justice and equity \\
& & - oneness, unity \\
& & - mutual respect for plurality/ diversity \\
& & - mobilising social networks \\
& & - living in a community
\end{tabular}

learning perspective They thus might reflect a more general opinion on how education contributes to individual development. I here find strong references to such behavioural and attitudinal aspects as creativity, critical thinking, resilience, responsiveness, self-awareness and assertiveness.

\subsection{Teaching and learning}

Many organisations define new models of interaction between teachers and students. For teachers, the future of education means to 'adapt teaching strategies to individual needs' (OECD 2008, 9) based on 'continual identification of and responses to students' needs' creating a 'learning environment that is sensitive to their pre-existing structures'. For the Pacific Island Forum it is vital to stimulate 'lifelong, purposive, self-planned and self-initiated learning' (PIF 2007, 4). Designing 'individualized learning plans' (WB 2003b, xx) and 'a greater sense of "managerial” (professional) responsibility for curricula development and change' (ILO 2000b, 1) would then be part of the new teaching mission. Teaching in the future would redefine didactic approaches towards more 'active, inclusive and participatory learning' (UNICEF 2012:3; AAI 2013; PIF 2015) where students make their own 'action-based' (CoE 2007, 11) learning experience in a more 'contextual' and 'transversal' curriculum (LAS 2008, 32). Teachers would, in short, become 'guides, mentors and mediators' (EU 2000, 17; also EI 2012, 13).

The role of schools is highly underspecified. In some of the few references, schools should be given 'more autonomy [...] as they develop a base for community life-long learning' (OECS 2001:8) and can become 'multimedia centres' or 'community learning centres' (OECD 2008, 7; UNESCO 2009). In general, IOs hold that educational offers ought to be 'tailored to meet individual needs' creating a 'demand-led' or 'learner-driven' (WB 2003b, 58) and 'customized' (OECD 2008, 9) education system where people can store and document their educational assets in individual learning accounts (APEC 2004, 10).

More specialised learn-theoretical reflections can mostly be found in larger IGOs, particularly the UNESCO and OECD. In its highly academic 21st' Century Learning: Research, Innovation and Policy Directions from recent OECD analyses the OECD, for instance, $(2008,2)$ stresses

the importance of learning deeper conceptual understanding, rather than superficial facts and procedures, the importance of learning connected and coherent knowledge, rather than knowledge compartmentalized into distinct subjects and courses, the importance of learning authentic knowledge in its context of use, rather 
than decontextualized classroom exercises and the importance of learning collaboratively, rather than in isolation.

The role of information and communication technology (ICT) in such a learner-centred curriculum is ubiquitous. It can take the form of open and distance learning organised at virtual universities (AFDB 2004) along with 'digital libraries and resource centers' (CARICOM 2011, 49; UNESCO 2011, 19) and 'Education Hot Spots' USAID 2007, 7), creating global 'communities of practice' (UNESCO 2011, 19) enabling learners to learn independently and self-directed. ICT promises to reach the hitherto unreached: nomads, rural and remote populations and those wanting to learn 'round-the-clock' and 'on-the-move' (EU 2000, 19).

ICT is one of the few cases where discourses do somewhat differ with regions of less socioeconomic development showing more interest in the issue (See Table 1). Although this is not a rule. The EU $(2000,19)$, for example, wants to 'provide lifelong learning and education opportunities as close to learners as possible, in their own communities and supported through ICT-based facilities wherever appropriate [...]' as 'ICT offers great potential for reaching scattered and isolated populations [...]'. So do organisations from developing areas where ICT are considered having 'the potential to overcome problems of distance and can be organized in more cost effective ways' (SADC 2007, 58).

\section{Discussion}

Analysis shows that international organisations show growing interest in curricular questions. Such active involvement increases over time and, surprisingly, with little differences across specific types of IOs or their geographic scope including governmental and non-governmental organisations, development banks and agencies alike, which have received little attention in relevant scholarship. To be sure, most and the most elaborate references come from large, global and well-known organisations, yet the field is widening rapidly. Importantly, on the substantive side, recommendations to do not differ as one might expect. This supports previous arguments about a highly dynamic and increasingly dense as well as isomorphic international organisational field concerned with education (Chabbott 2003; Zapp and Dahmen 2017).

In general, we may ask why IOs' interest in curricular questions has emerged and what are IOs' interests in such curriculum work. One important change is that educational expertise has grown considerably in a wide range of IOs. Based on bibliometric data from 1,325 international governmental and non-governmental organisations, Zapp (2017a) finds that academic publications in education come 6 th out of 20 issue areas, with a striking increase since the late 1990s. Although IGOs are more productive than INGOs, both types have vastly expanded their research portfolio and output, with both types producing more research in the past 15 years than in the four previous decades. Other more case-based studies show similar trends of expansive scientization in education for UNESCO (Robinson, Edwards et al. 2018), OECD (Bürgi 2016), WB (Zapp 2017b), and a wide range of non-governmental education organisations (Bromley 2010). Changes in staff structure and the skill profile of that staff allow IOs to engage with topics that had been unchartered territory before as research knowledge and evidence becomes the basis for policy expertise (Chabbott 2003; Zapp $2017 b)$ - curriculum work might be one example for such expansion.

A second reason is that education has come to be seen unanimously as the main engine of individual and social development among a growing number of IOs. The quality imperative that emerged in the wake of the EFA initiative has led many IOs to go beyond simple enrolment goals and to focus on classroom activities (Zapp 2018). This is partly documented in the growing interest in output measurement (Smith 2019), but also through the interest in learning processes and a focus on the student itself. Such a shift is supported by the findings in this study. Curricular elements identified in the analysis reflect some of the major trends reported in cross-national curriculum research, while revealing additional features less discussed in the literature. 
Frequent and detailed references to goals of empowerment and individual development on the one hand and economic development and employability on the other suggest a compromise between human rights, capabilities and human capital, a somewhat uncomfortable compromise observed to take shape on the global educational agenda in general (Mundy 2007; Parreira do Amaral 2010). While previous studies have stressed that national curricular goals follow an underlying logic of 'national development through individual achievement' (Rosenmund 2003), the explicit national frame is less salient in this sample of IOs (see below).

The emphasis on empowerment and individual, often psychosocial, development is striking. Throughout the organisational sample, education is believed to equip individuals with what it takes to become an effective modern actor and such depictions sometimes give the impression that they were copied verbatim from a psychology textbook (e.g., 'self-awareness', 'resilience', 'assertiveness'). Such a 'psychological turn' had already been observed at the OECD (Zapp 2018) but seems to reach other organisations quickly.

The subjects recommended constitute the core of the 'global curriculum' identified by Benavot et al. (1991), Kamens and Benavot (1991) and Cha and Ham (2011) including instruction in (official) language, mathematics, natural science, and social sciences. The frequent references to human rights and diversity as well as the global environment are in line with findings from Bromley and Suarez (2012), Bromley (2014) and Bromley, Meyer, and Ramirez (2011).

More striking is, however, the remarkable emphasis on a variety of 'competences'. These bundle skills, attitudes, dispositions and values or, more generally, cognitive, emotional and psychosocial personality traits. The focus on behavioural aspects is explicit. The OECD $(1996,89$-ff.) considers the 'dispositions, values and attitudes of individuals' as within the 'realm of legitimate policy intervention'. The EU (2001) proposes to launch debates for implementing education and learning 'in all spheres of public and private life' (EU 2001,3).

IOs' discourse on these competences is highly optimistic, if not unrealistic. LAS $(2008,32)$ envisions an 'all-able personality' and SNV $(2007,13)$ believes that the required competences help learners 'function as physical, social, intellectual, moral or spiritual and emotional human beings.'

I argue that IOs' work on international large-scale testing underpins their growing interest in both the educational content (i.e., curriculum) and the causal mechanisms of educational achievement. Both questions have brought IOs to the particular role of the individual and its psychosocial qualities. The role of individuals in the development discourse has, since the late 1990s, been increasingly linked to the idea of empowerment with education as the principal tool (Calvès 2009). A strong involvement of psychology and, more recently, neuroscience in education have added up to a markedly different educational discourse in the past decade (Anderson and Della Sala 2012). Such developments have not remained unnoticed by international actors.

The strong focus on individual development and cross-curriculum skills might also explain why IOs often leave educational levels undefined or very vague. The generality of these competences also allows IOs to apply them to the wide array of learner groups.

IOs' suggestions for teaching and learning processes mirror the cross-national shift away from canonical learning towards active student-centred learning (McEneaney 1998; Bromley, Meyer, and Ramirez 2011). The focus on self-directed learning, teachers as mentors and the strong reliance on ICT stress a highly individualised or personalised curriculum and relates to the strong responsibility given to the individual learner (Rosenmund 2003).

The educational vision that emerges in these documents is radically 'purified' and decontextualised. It removes the student from the system by replacing it with the 'learner', remaining silent on the level and even on the setting (formal, non-formal, informal). It dis-embeds learners from local and national history and culture by referring to a 'universal identity in an interdependent world' (LAS 2008, 40), the 'perception of being a world citizen' (EU 2005, 57), the 'common heritage of mankind' (AU 2006, 5) and other instances of global society and transnational citizenship (OECD 1996, 100f.; UNESCO 1990, 25). If such a trend has become observable in a national context (Wong 1991; Rauner 1998), it should not surprise that such instances are even more strongly 
articulated at the international level. Interestingly, this vision even abstracts from any canonical, subject-based curriculum by stressing competences and personality more than instructional blueprints. Instead of prescribing what the ideal curriculum should look like and how individuals should fit into this curriculum, the point of departure is the individual psychology itself that is to be empowered to be able to create its own learning process.

Institutionalist research has long stressed that education is 'institutionally chartered to be universal, standardized, and rationalized'; 'very highly institutionalized at a very general collective level'; and institutionally chartered to conduct the socialization of the individual as the central social unit' (Boli, Ramirez, and Meyer 1985, 147-149). A growing number of IOs have come to represent this 'collective level' in the more recent globalised period and they take on this role through much normative agenda-setting and knowledge work. Such a shift should prompt education researchers interested in the role of IOs in education and the causes for isomorphic national curriculum change to make the level of international organisations a routine level of analysis.

\section{Conclusion}

Research interested in the role of international organisations in education policymaking has paid little attention to the burgeoning curriculum agenda at the international level. The analysis presented in this article has identified a large sample of regional and global, intergovernmental and nongovernmental international organisations actively engaged in formulating curriculum goals, content as well as definitions of the profile and role of learners. Commitment to such an international curricular discourse has seen a remarkable boost since the early 2000s. Individual empowerment beyond collective or national goals looms large in these recommendations. The suggested curriculum content reflects much cross-national change towards the modern core subjects and, more importantly, puts a remarkable emphasis on cross-curriculum competences and psychosocial capabilities of individual learners. Such a decontextualised and 'stylised' individual as the primary actor in this curriculum is supported by few references to specific educational levels and settings and a strong premium on student-centred, self-directed and individualised teaching and learning.

The findings suggest new analytical opportunities in the study of IOs in education and crossnational curriculum research as IOs, through normative agenda setting and knowledge diffusion, might contribute to catalyse isomorphic change in national curricula worldwide. Future research would benefit from tracing the implementation of IOs' curriculum recommendations in national policy in order to better understand how international debates impact upon national systems in this important field of educational policy.

\section{Notes}

1. See UNESCO (2016), Global Campaign for Education (2016) and UN (2016) for member organisations in these networks.

2. The complete coding structure including the specific references per category and concept is available on request.

\section{Acknowledgements}

I would like to thank Clarissa Dahmen, Marcelo Marques, John Meyer, Justin Powell and the anonymous reviewers for helpful comments on earlier versions of this paper.

\section{Disclosure statement}

No potential conflict of interest was reported by the author. 


\section{References}

Anderson, M., and S. Della Sala. 2012. Neuroscience in Education: The Good, the Bad, and the Ugly. Oxford: Oxford University Press.

Baker, D. P. 2015. "A Note on Knowledge in the Schooled Society: Towards an End to the Crisis in Curriculum Theory." Journal of Curriculum Studies 47 (6): 763-772.

Baker, D. P., and A. W. Wiseman. 2005. Global Trends in Education Policy. Amsterdam: Elsevier.

Benavot, A., Y. K. Cha, D. Kamens, J. W. Meyer, and S. Y. Wong. 1991. "Knowledge for The Masses: World Models and National Curricula, 1920-1986.” American Sociological Review 56 (1): 85-100.

Benavot, A., and H. D. Meyer. 2013. PISA, Power, and Policy: The Emergence of Global Educational Governance. Oxford: Symposium Books.

Benavot, A., and P. Riddle. 1988. "The Expansion of Primary Education, 1870-1940: Trends and Issues." Sociology of Education 61 (3): 191-210.

Boli, J., F. O. Ramirez, and J. W. Meyer. 1985. "Explaining the Origins and Expansion of Mass Education." Comparative Education Review 29 (2): 145-170.

Bromley, P. 2010. "The Rationalization of Educational Development: Scientific Activities among International NonGovernmental Organizations." Comparative Education Review 54 (4): 577-601.

Bromley, P. 2014. "Legitimacy and the Contingent Diffusion of World Culture: Diversity and Human Rights in Social Science Textbooks, Divergent Cross-National Patterns (1970-2008).” Canadian Journal of Sociology 39 (1): 1-44.

Bromley, P., J. W. Meyer, and F. O. Ramirez. 2011. "Student Centrism in Social Science Textbooks: 1970-2005." Social Forces 90 (2): 1-24.

Bromley, P., and D. S. Suarez. 2012. "Institutionalizing a Global Social Movement: Human Rights as University Knowledge." American Journal of Education 118 (3): 253-280.

Bürgi, R. 2016. "The Free World and the Cult of Expertise. The Rise of OECD's Educationalizing Technocracy." International Journal for the Historiography of Education 6 (2): 159-175.

Calvès, A.-E. 2009. “"Empowerment» : généalogie d'un concept clé du discours contemporain sur le développement.” Revue Tiers Monde 200 (4): 735-749.

Cha, Y. K., and S. H. Ham. 2011. "Educating Supranational Citizens: The Incorporation of English Language Education into Curriculum Policies." American Journal of Education 117: 183-209.

Chabbott, C. 2003. Constructing Education for Development: International Organizations and Education for All. New York: Routledge Falmer.

Corbin, J., and A. Strauss. 2008. Basics of Qualitative Research. 3rd ed. Thousand Oaks: Sage.

Cummings, W. K. 2003. The Institutions of Education: A Comparative Study of Educational Development in the six Core Nations. Oxford: Symposium.

Dale, R. 2005. "Globalisation, Knowledge Economy and Comparative Education." Comparative Education 41 (2): 117-149.

Edwards, D. B., T. Okitsu, R. da Costa, and Y. Kitamura. 2018. "Organizational Legitimacy in the Global Education Policy Field: Learning from UNESCO and the Global Monitoring Report.” Comparative Education Review 62 (1): 31-63.

Finnemore, M. 1993. "International Organizations as Teachers of Norms: the United Nations Educational, Scientific, and Cultural Organization and Science Policy.” International Organization 47 (4): 565-597.

Frank, D. J., and J. Gabler. 2006. Reconstructing the University: Worldwide Shifts in Academia in the 20th Century. Stanford, CA: Stanford University Press.

Global Campaign for Education. 2016. The Global Campaign for Education Partners. Accessed December 9, 2016. http://www.campaignforeducation.org/en/members/international.

Gorur, R. 2014. "Towards a Sociology of Measurement in Education Policy." European Educational Research Journal 13 (1): 58-72.

Heyneman, S. P., and C. Lykins. 2008. “The Evolution of Comparative and International Education Statistics.” In Handbook of Research in Education Finance and Policy, edited by H. F. Ladd and E. B. Fiske, 105-127. NewYork: Routledge.

Hopmann, S. T. 2003. "On the Evaluation of Curriculum Reform.” Journal of Curriculum Studies 35 (4): 459-478.

Jakobi, A. P. 2006. The Worldwide Norm of Lifelong Learning. A Study of Global Policy Development. Germany: University of Bielefeld.

Jakobi, A. P. 2009. "Global Education Policy in the Making: International Organisations and Lifelong Learning." Globalisation, Societies and Education 7 (4): 473-487. doi:10.1080/14767720903412275.

Jakobi, A. P. 2012. "Facilitating Transfer: International Organizations as Central Nodes for Policy Diffusion.” In World Yearbook of Education. Policy Borrowing and Lending, edited by G. Steiner-Khamsi and F. Waldow, 391-407. London: Routledge.

Kallo, J. 2006. "Soft Governance and Hard Values: A Review of OECD Operational Processes within Educational Policy and Relations with Member States." In Supranational Regimes and National Education Policies - 
Encountering Challenge, edited by J. Kallo and R. Rinne, 261-352. Turku: Finnish Educational Research Association.

Kamens, D. H., and A. Benavot. 1991. "Elite Knowledge for the Masses: The Origins and Spread of Mathematics and Science Education in National Curricula." American Journal of Education 99: 137-180.

Klabbers, J. 2018. An Introduction to International Organizations Law. Cambridge: Cambridge University Press.

Komljenovic, J., and S. L. Robertson. 2016. “The Dynamics of 'Market-Making' in Higher Education.” Journal of Education Policy 31 (5): 622-636.

Martens, K. 2007. "How to become an Influential Actor - the 'Comparative Turn' in OECD Education Policy." In New Arenas of Education Governance - The Impact of International Organisations and Markets on Educational Policymaking, edited by K. Martens, A. Rusconi, and K. Leuze, 40-56. Basingstoke: Palgrave.

McEneaney, E. H. 1998. The Transformation of Primary School Science and Mathematics: A Cross-National Analysis, 1990-1995. California: Stanford University.

McNeely, C. 1995. "Prescribing National Education Policies: The Role of International Organizations." Comparative Education Review 39 (4): 483-507.

Meyer, J. W., J. Boli, G. M. Thomas, and F. O. Ramirez. 1997. "World Society and the Nation-State." American Journal of Sociology 103 (1): 144-181.

Mundy, K. 2007. "Educational Multilateralism - Origins and Indications for Global Governance." In New Arenas of Education Governance. The Impact of International Organizations and Markets on Educational Policy Making, edited by K. Martens, A. Rusconi, and K. Leuze, 19-40. Basingstoke: Palgrave Macmillan.

Mundy, K., and M. Ghali. 2009. "International and Transnational Policy Actors in Education: A Review of the Research." In Handbook on Educational Policy Research, edited by D. Plank, G. Sykes, and B. Schneider, 717734. cc: The American Education Research Association and Routledge Press.

Mundy, K., and A. Verger. 2015. "The World Bank and the Global Governance of Education in a Changing World Order.” International Journal of Educational Development 40: 9-18.

Parreira do Amaral, M. 2010. "Regime Theory and Educational Governance: The Emergence of an International Education Regime.” In International Educational Governance, edited by S. K. Amos, 57-78. Bingley, UK: Emerald.

Power, M. 2004. "Counting, Control and Calculation: Reflections on Measuring and Management.” Human Relations 57: 765-783.

Rappleye, J. 2011. "Catalysing Educational Development or Institutionalising External Influence? Donors, Civil Society and Educational Policy Formation in Nepal." Globalisation, Societies and Education 9 (1): 27-49. doi:10.1080/ 14767724.2010.513517.

Rauner, M. 1998. The Worldwide Globalization of Civics Education Topics, 1955-1995. California: Stanford University.

Rosenmund, M. 2000. "Approaches to International Comparative Research on Curricula and Curriculum-Making Processes.” Journal of Curriculum Studies 32 (5): 599-606.

Rosenmund, M. 2003. World Trends in Curricula Change. Content Analysis of National Reports on Education. Geneva: International Bureau of Education: UNESCO.

Rosenmund, M. 2006. "The Current Discourse on Curriculum Change: A Comparative Analysis of National Reports on Education." In School Knowledge in Comparative and Historical Perspective, edited by A. Benavot and C. Braslavsky, 173-194. Hong Kong: Comparative Education Research Center /Springer.

Schemmann, M. 2007. Internationale Weiterbildungspolitik und Globalisierung. Bielefeld: Bertelsmann.

Scherrer, C. 2007. "GATS - Commodifying Education via Trade Treaties." In New Arenas of Education Governance, edited by K. Martens, A. Rusconi, and K. Leuze, 117-135. London: Palgrave.

Schuetze, H. G., and M. Slowey. 2000. "Traditions and New Directions in Higher Education - A Comparative Perspective Non-Traditional Students and Lifelong Learners." In Higher Education and Lifelong Learners. International Perspectives on Change, edited by H. G. Schutze and M. Slowey, 3-25. London and New York: Routledge.

Smith, W. 2019. The Global Testing Culture. Shaping Education Policy, Perceptions, and Practice. Oxford: Symposium.

UN. 2016. UN Millennium Development Goals Partners. Accessed December 9, 2016. http://www.un.org/ millenniumgoals/partners.shtml.

UNESCO. 2016. Education For All Partners. Accessed December 9, 2016. http://www.unesco.org/new/en/education/ themes/ leading-the-international-agenda/education-for-all/partners/international-organizations/.

Union of International Associations. 2017. International Congress Calendar. Brussels: UIA.

Westbury, I., et al. 2016. "Organizing Curriculum Change: An Introduction.” Journal of Curriculum Studies 48 (6): 729-743. doi:10.1080/00220272.2016.1186736.

Wong, S. Y. 1991. "The Evolution of Social Science Instruction, 1900-1986: A Cross-national Study." Sociology of Education 64 (1): 33-47.

Young, M. 2013. "Overcoming the Crisis in Curriculum Theory: A Knowledge-Based Approach." Journal of Curriculum Studies 45 (2): 101-118. doi:10.1080/00220272.2013.764505.

Zapp, M. 2017a. "The Scientization of the World Polity. International Organizations and the Production of Scientific Knowledge, 1950-2015.” International Sociology 33 (1): 3-26. doi:10.1177/0268580917742003. 
Zapp, M. 2017b. “The World Bank and Education: Governing (Through) Knowledge.” International Journal of Educational Development 53: 1-11. doi:10.1016/j.ijedudev.2016.11.007.

Zapp, M. 2018. "Beyond Large-Scale Achievement Testing - The Psychological Turn in International Organizations' Work on Educational Assessment.” In Cross-nationally Comparative, Evidence-Based Educational Policymaking and Reform, edited by A. Wiseman et al, 161-197. Bingley, UK: Emerald.

Zapp, M., and C. Dahmen. 2017. "The Diffusion of Educational Ideas-An Event History Analysis of Lifelong Learning, 1990-2015.” Comparative Education Review 61 (3): 492-518. doi:10.1086/692607.

Zapp, M., and J. J. W. Powell. 2016. "How to Construct an Organizational Field: Empirical Educational Research in Germany, 1995-2015.” European Educational Research Journal 15 (5): 537-557. doi:10.1177/1474904116641422.

\section{Appendices}

Table A1. Organization and document sample.

\begin{tabular}{|c|c|c|c|c|c|}
\hline Organization & Abbrev. & Found. & Type & A. & \\
\hline $\begin{array}{l}\text { ActionAid } \\
\text { International }\end{array}$ & AAI & 1972 & INGO & $\mathrm{N}$ & $\begin{array}{l}\text { AAI (2013) Action for Children's Rights in Education - Policy Brief. } \\
\text { Accessed 13/08/2015, http://www.actionaid.org/publications/ } \\
\text { promoting-rights-schools-providing-quality-public-education } \\
\text { AAl (2011) Education Rights - A guide for practitioners and } \\
\text { activists, http://www.actionaid.org/sites/files/actionaid/1._- } \\
\text { education_rights_-_a_guide_for_practitioners_and_activists.pdf }\end{array}$ \\
\hline $\begin{array}{l}\text { African } \\
\text { Development } \\
\text { Bank }\end{array}$ & AFDB & 1964 & Bank & $\mathrm{S}$ & $\begin{array}{l}\text { AFDB (2004) African Virtual University Support Project. Côte d'Ivoire. } \\
\text { Accessed 17/07/2015, http://www.afdb.org/fileadmin/uploads/ } \\
\text { afdb/Documents/Project-and-Operations/MN-2004-155-EN-ADF- } \\
\text { BD-WP-MUTTINATIONAL-AFRICAN-VIRTUAL-UNIVERSITY.PDF } \\
\text { AFDB (2007a) Education Quality Enhancement Project (Education III). } \\
\text { Côte d'Ivoire. Accessed 17/07/2015, } \\
\text { http://www.afdb.org/fileadmin/uploads/afdb/Documents/ } \\
\text { Project-and-Operations/LS-2007-013-EN-ADF-BD-WP-REV.1- } \\
\text { LESOTHO-AR-EDUCATION-QUALITY-ENHANCEMENT-PROJECT- } \\
\text { REV.1.PDF } \\
\text { AFDB (2007b) Technical and Vocational Skills Development. Hong } \\
\text { Kong. Accessed 17/07/2015, http://www.afdb.org/fileadmin/ } \\
\text { uploads/afdb/Documents/Generic-Documents/005_04_EN_- } \\
\text { Network_for_Policy_Research_Review.pdf }\end{array}$ \\
\hline African Union & $\mathrm{AU}$ & 2001 & $\begin{array}{l}\text { Regional } \\
\text { IGO }\end{array}$ & $S$ & $\begin{array}{l}\text { AU (2006) African Youth Charter. Banjul. Accessed 16/07/2015, } \\
\text { http://africa-youth.org/sites/default/files/ } \\
\text { AFRICAN_YOUTH_CHARTER.pdf }\end{array}$ \\
\hline $\begin{array}{l}\text { Agence Française } \\
\text { de } \\
\text { Développement }\end{array}$ & AFD & 1941 & Agency & $\mathrm{N}$ & $\begin{array}{l}\text { AFD (2006) Apprendre pour vivre et travailler: contribution du GEFOP } \\
\text { au Rapport sur le développement dans le monde } 2007 \text { de la } \\
\text { Banque mondiale. Paris. Accessed 17/07/2015, } \\
\text { http://www.afd.fr/webdav/shared/PUBLICATIONS/RECHERCHE/ } \\
\text { Scientifiques/Documents-de-travail/014-document-travail.pdf } \\
\text { AFD (2015) 'Éducation de base pour tous. Paris. Accessed 17/07/ } \\
\text { 2015, } \\
\text { http://www.afd.fr/home/projets_afd/education/education-de- } \\
\text { base }\end{array}$ \\
\hline $\begin{array}{l}\text { Andean } \\
\text { Community }\end{array}$ & CAN & 1996 & $\begin{array}{l}\text { Regional } \\
\text { IGO }\end{array}$ & $\mathrm{S}$ & $\begin{array}{l}\text { CAN (2004) Comunidad Andina. Estrategias sindicales frente al } \\
\text { empleo. Lima. Accessed 16/07/2015, } \\
\text { http://www.pazysolidaridad.ccoo.es/ficheros/documentos/57_- } \\
\text { cuaderno13\%20-\%20Uni\%F3n\%20europea\%20y\%20comunidad } \\
\text { \%20andina.pdf }\end{array}$ \\
\hline $\begin{array}{l}\text { Asia-Pacific } \\
\text { Economic } \\
\text { Cooperation }\end{array}$ & APEC & 1989 & $\begin{array}{l}\text { Regional } \\
\text { IGO }\end{array}$ & $\mathrm{S}$ & $\begin{array}{l}\text { APEC (1999) Women Entrepreneurs in SMEs in the APEC Region. } \\
\text { Taejon-City. Accessed 16/07/2015, http://www.apec.org/About- } \\
\text { Us/How-APEC-Operates/ / /media/Files/Groups/GFPN/\%2099_ } \\
\text { aggi_entrep.ashx } \\
\text { APEC (2004) } 2004 \text { APEC Symposium Practices for fostering a Lifelong } \\
\text { Learning Society. Taipei. Accessed 16/07/2015, http:// } \\
\text { publications.apec.org/publication-detail.php?pub_id=1057 }\end{array}$ \\
\hline $\begin{array}{l}\text { Asian Development } \\
\text { Bank }\end{array}$ & $A D B$ & 1965 & Bank & $S$ & $\begin{array}{l}\text { ADB (2007) Uzbekistan: Senior Secondary Education Project. } \\
\text { Mandaluyong City. Accessed 08/01/2013 http://www.adb.org/ } \\
\text { documents/uzbekistan-senior-secondary-education-project }\end{array}$ \\
\hline
\end{tabular}


Table A1. Continued.

\begin{tabular}{|c|c|c|c|c|c|}
\hline Organization & Abbrev. & Found. & Type & A. & \\
\hline & & & & & $\begin{array}{l}\text { ADB (2009) Proposed Asian Development Fund Grant and Loan for } \\
\text { Subprogram III Nepal: Education Sector Program. Mandaluyong } \\
\text { City. Accessed 08/01/2013, http://catalog.hathitrust.org/Record/ } \\
006768655\end{array}$ \\
\hline $\begin{array}{l}\text { Association of } \\
\text { South East Asian } \\
\text { Nations }\end{array}$ & ASEAN & 1967 & $\begin{array}{l}\text { Regional } \\
\text { IGO }\end{array}$ & $\mathrm{S}$ & $\begin{array}{l}\text { ASEAN (2009) Roadmap for an ASEAN Community 2009-2015. } \\
\text { Jakarta. Accessed 17/07/2015, } \\
\text { http://www.meti.go.jp/policy/trade_policy/asean/dl/ } \\
\text { ASEANblueprint.pdf }\end{array}$ \\
\hline $\begin{array}{l}\text { Caribbean } \\
\text { Community }\end{array}$ & CARICOM & 1973 & $\begin{array}{l}\text { Regional } \\
\text { IGO }\end{array}$ & $\mathrm{S}$ & $\begin{array}{l}\text { CARICOM (2009) Concept Paper for the Development of a CARICOM } \\
\text { Strategic Plan for Vocational Education Services. Georgetown. } \\
\text { Accessed 16/07/2015, http://www.caricom.org/jsp/single_- } \\
\text { market/services_regime/concept_paper_vocational_education. } \\
\text { pdf } \\
\text { CARICOM (2011) Draft Regional Information and Communication } \\
\text { Technology (ICT) for Development Strategy. Georgetown. Accessed } \\
\text { 16/07/2015, } \\
\text { http://www.gov.ms/wp-content/uploads/2011/02/Draft-RDdS- } \\
\text { Nov-2010.pdf }\end{array}$ \\
\hline Council of Europe & $\mathrm{CoE}$ & 1949 & $\begin{array}{l}\text { Regional } \\
\text { IGO }\end{array}$ & $\mathrm{N}$ & $\begin{array}{l}\text { CoE ( 2007) CDED Summary Progress Report. Strasbourg. Accessed } \\
\text { 16/07/2015, www.coe.int/t/dg4/linguistic/ ... /Rapport_ComEd_ } \\
\text { mars07_web_EN.doc }\end{array}$ \\
\hline $\begin{array}{l}\text { Council of Europe } \\
\text { Development } \\
\text { Bank }\end{array}$ & CoEDB & 1956 & $\begin{array}{l}\text { Regional } \\
\text { IGO }\end{array}$ & $\mathrm{N}$ & $\begin{array}{l}\text { CEB (2006) La cohésion sociale, condition de la croissance? Paris. } \\
\text { Accessed 17/07/2015, http://www.coebank.org/upload/ } \\
\text { infocentre/Brochure/bilingue/Actes.pdf }\end{array}$ \\
\hline $\begin{array}{l}\text { Department for } \\
\text { International } \\
\text { Development }\end{array}$ & DFID & 1997 & Agency & $\mathrm{N}$ & $\begin{array}{l}\text { DFID (2004) Ghana Literacy Project. https://www.gov.uk/ } \\
\text { government/uploads/system/uploads/attachment_data/file/ } \\
\text { 67872/ev586.pdf } \\
\text { DFID (2011a) Information provided by longitudinal assessment data } \\
\text { helps } \\
\text { governments and schools improve learning achieveme. Bristol. } \\
\text { Accessed 17/07/2015, } \\
\text { http://www.edqual.org/publications/policy-briefs/edqualpb11 } \\
\text { DFID (2011b) Education for children with disabilities - improving } \\
\text { access and qualityA DFID practice paper. London. Accessed 17/07/ } \\
\text { 2015, https://www.gov.uk/government/uploads/system/ } \\
\text { uploads/attachment_data/file/67664/edu-chi-disabil-guid-note. } \\
\text { pdf } \\
\text { DFID (2011c) Engaging the Private Sector in Skills Development. } \\
\text { London. Accessed 17/07/2015, https://www.gov.uk/government/ } \\
\text { uploads/system/uploads/attachment_data/file/67623/eng-priv- } \\
\text { sect-skills-dvmt.pdf }\end{array}$ \\
\hline $\begin{array}{l}\text { East African } \\
\text { Community }\end{array}$ & EAC & 2000 & $\begin{array}{l}\text { Regional } \\
\text { IGO }\end{array}$ & $\mathrm{S}$ & $\begin{array}{l}\text { EAC (2009) Study on the Harmonization of the East African Education } \\
\text { Systems. Final Report. Arusha. Accessed 16/07/2015, } \\
\text { www.eac.int/rmo/index.php?option=com_docman\&task=doc }\end{array}$ \\
\hline $\begin{array}{l}\text { Economic and } \\
\text { Social Council }\end{array}$ & $\mathrm{ECOSOC}$ & 1945 & IGO & G & $\begin{array}{l}\text { ECOSOC (2011) Theme of the annual ministerial review: } \\
\text { implementing the internationally agreed goals and committents in } \\
\text { regard to education - Report of the Secretary-General. Geneva. } \\
\text { Accessed 15/07/2015, http://portal.unesco.org/geography/es/ } \\
\text { files/13904/13015146765implementing-internationally-agreed- } \\
\text { goals-education.pdf/implementing-internationally-agreed-goals- } \\
\text { education.pdf }\end{array}$ \\
\hline $\begin{array}{l}\text { Economic } \\
\text { Community of } \\
\text { West African } \\
\text { States }\end{array}$ & ECOWAS & 1975 & $\begin{array}{l}\text { Regional } \\
\text { IGO }\end{array}$ & $\mathrm{S}$ & $\begin{array}{l}\text { ECOWAS (2009) ECOWAS Ministers adopt Labour Policy, Plan of } \\
\text { Action. Grand Bassam. Accessed 16/07/2015, http://news.ecowas. } \\
\text { int/presseshow.php?nb=038\&lang=en\&annee }=2009\end{array}$ \\
\hline $\begin{array}{l}\text { Education } \\
\text { International }\end{array}$ & El-IE & 1993 & INGO & G & $\begin{array}{l}\text { EI-IE (2012) Future of Teaching Profession. Cambridge. Accessed 18/ } \\
\text { 07/2015, } \\
\text { http://download.ei-ie.org/Docs/WebDepot/El\%20Study\%20on\% } \\
\text { 20the\%20Future\%20of\%20Teaching\%20Profession.pdf }\end{array}$ \\
\hline $\begin{array}{l}\text { European Bank for } \\
\text { Reconstruction } \\
\text { and }\end{array}$ & EBRD & 1991 & Bank & $\mathrm{N}$ & $\begin{array}{l}\text { EBRD (2008) Transition Report 2008. London. Accessed 08/01/2015, } \\
\text { http://www.ebrd.com/downloads/research/transition/TR08.pdf }\end{array}$ \\
\hline
\end{tabular}

Development 
Table A1. Continued.

\begin{tabular}{|c|c|c|c|c|c|}
\hline Organization & Abbrev. & Found. & Type & A. & \\
\hline European Union & EU & 1952 & $\begin{array}{l}\text { Regional } \\
\text { IGO }\end{array}$ & $\mathrm{N}$ & $\begin{array}{l}\text { EU (1995) Teaching and Learning. Towards the Learning Society. } \\
\text { Brussels. Accessed 16/07/2015, } \\
\text { http://ec.europa.eu/languages/documents/doc409_en.pdf } \\
\text { EU (2000) A Memorandum on Lifelong Learning. Brussels. Accessed } \\
\text { 16/07/2015, http://www.bologna-berlin2003.de/pdf/ } \\
\text { MemorandumEng.pdf } \\
\text { EU (2001) Making a European Area of Lifelonf Learning a Reality. } \\
\text { Brussels. Accessed 16/07/2015, http://eur-lex.europa.eu/ } \\
\text { LexUriServ/LexUriServ.do?uri=COM:2001:0678:FIN:EN:PDF } \\
\text { EU (2005) Modernising education and training: a vital contribution to } \\
\text { prosperity and social cohesion in Europe. Brussels.Accessed 16/07/ } \\
\text { 2015, } \\
\text { http://ec.europa.eu/education/lifelong-learning-policy/doc/ } \\
\text { policy/report06staff_en.pdf } \\
\text { EU (2007a) Delivering lifelong learning for knowledge, creativity and } \\
\text { innovation". Draft 2008 joint progress report of the Council and the } \\
\text { Commission on the implementation of the "Education \& Training } \\
\text { 2010 Work Programme. Brussels. Accessed 16/07/2015, http:// } \\
\text { www.ipex.eu/IPEXL-WEB/dossier/document/SEC20071484FIN.do } \\
\text { EU (2007b) Key Competences for Lifelong Learning. European } \\
\text { Reference Framework. Brussels. Accessed 16/07/2015, http://ec. } \\
\text { europa.eu/dgs/education_culture/publ/pdf/ll-learning/ } \\
\text { keycomp_en.pdf } \\
\text { EU (2011) Progress Towards the Common European Objectiv in } \\
\text { Education and Training. Indicators and benchmarks 2010/2011. } \\
\text { Brussels. Accessed 16/07/2015, http://ec.europa.eu/education/ } \\
\text { lifelong-learning-policy/doc/report10/report_en.pdf } \\
\text { EU (2012) Council conclusions on the employability of graduates } \\
\text { from education and training. Brussels. Accessed 16/07/2015, } \\
\text { http://www.consilium.europa.eu/uedocs/cms_data/docs/ } \\
\text { pressdata/en/educ/130142.pdf }\end{array}$ \\
\hline $\begin{array}{l}\text { Gesellschaft für } \\
\text { Internationale } \\
\text { Zusammenarbeit }\end{array}$ & $\mathrm{GIZ}$ & 2011 & Agency & $\mathrm{N}$ & $\begin{array}{l}\text { GIZ (2011a) Strengthening training organisations in partner countries } \\
\text { (capacity to build capacity). Eschborn. Accessed 17/07/2015, } \\
\text { http://www.giz.de/de/downloads/giz2011-en-strengthening- } \\
\text { training-organisations.pdf }\end{array}$ \\
\hline $\begin{array}{l}\text { Global March } \\
\text { against Child } \\
\text { Labor }\end{array}$ & GMCL & 1998 & INGO & $M$ & $\begin{array}{l}\text { GMCL (2014) Policy Paper - Out-of school children and child labor. } \\
\text { Accessed 14/08/2015 } \\
\text { http://www.globalmarch.org/content/policy-paper-out-school- } \\
\text { children-and-child-labour }\end{array}$ \\
\hline $\begin{array}{l}\text { Inter-American } \\
\text { Development } \\
\text { Bank }\end{array}$ & IADB & 1959 & Bank & M & $\begin{array}{l}\text { IDB (2009) A } \$ 48.75 \text { million loan for the first phase of a program to } \\
\text { improve the quality and equity of education services. Washington } \\
\text { DC. Accessed 17/07/2015, } \\
\text { http://www.iadb.org/en/news/news-releases/2009-05-20/idb- } \\
\text { backs-trinidad-and-tobagos-seamless-education-system,5418. } \\
\text { html }\end{array}$ \\
\hline $\begin{array}{l}\text { International } \\
\text { Labour } \\
\text { Organization }\end{array}$ & ILO & 1919 & IGO & G & $\begin{array}{l}\text { ILO (2000a) Resolution concerning human resources training and } \\
\text { development[3] Accessed 15/07/2015, } \\
\text { http://www.ilo.org/public/english/standards/relm/ilc/ilc88/ } \\
\text { resolutions.htm\#III } \\
\text { ILO (2000b) Press release, ILO News. Geneva. Accessed 08/01/2015 } \\
\text { ILO (2003) Press release, ILO News: Lifelong Learning a 'Win-Win' } \\
\text { Opportunity for Enterprises, Workers. Bankok. Accessed 15/07/ } \\
\text { 2015, } \\
\text { http://www.ilo.org/asia/info/public/pr/WCMS_BK_PR_78_EN/ } \\
\text { lang--en/index.htm } \\
\text { ILO (2004) Recommendation concerning Human Resources } \\
\text { Development: } \\
\text { Education, Training and Lifelong LearningAdoption. Geneva. } \\
\text { Accessed 15/07/2015, } \\
\text { http://www.ilo.org/dyn/normlex/en/f?p=1000:12100:0::NO:: } \\
\text { P12100_ILO_CODE:R195 }\end{array}$ \\
\hline
\end{tabular}


Table A1. Continued.

\begin{tabular}{|c|c|c|c|c|c|}
\hline Organization & Abbrev. & Found. & Type & A. & \\
\hline $\begin{array}{l}\text { International } \\
\text { Monetary Fund }\end{array}$ & IMF & 1945 & IGO & $\mathrm{G}$ & $\begin{array}{l}\text { IMF (2006) Serbia and Montenegro: Poverty Reduction Strategy Paper } \\
\text { - Progress Reports. Washington DC. Accessed 15/07/2015, } \\
\text { http://www.imf.org/external/pubs/ft/scr/2006/cr06141.pdf } \\
\text { IMF (2012) Ghana: Poverty Reduction Strategy Paper. Washington } \\
\text { DC. Accessed 15/07/2015, http://www.imf.org/external/pubs/ft/ } \\
\text { scr/2012/cr12203.pdf }\end{array}$ \\
\hline $\begin{array}{l}\text { Islamic } \\
\text { Development } \\
\text { Bank }\end{array}$ & IDB & 1975 & Bank & $S$ & $\begin{array}{l}\text { IDB (2006) A Vision for Human Digity. Vision 1440H. Dubai. Accessed } \\
\text { 17/07/2015, http://www.isdb.org/irj/go/km/docs/documents/ } \\
\text { IDBDevelopments/Internet/English/IDB/CM/About\%20IDB/IDB\% } \\
\text { 201440H\%20Vision/IDB_1440HVision_report-no_images.pdf }\end{array}$ \\
\hline $\begin{array}{l}\text { Japan International } \\
\text { Cooperation } \\
\text { Agency }\end{array}$ & JICA & 2003 & Agency & $\mathrm{N}$ & $\begin{array}{l}\text { JICA (2007) Cambodia: Country Gender. Tokyo. Accessed 17/07/ } \\
\text { 2015, http://www.jica.go.jp/english/our_work/thematic_issues/ } \\
\text { gender/background/pdf/e07cam.pdf } \\
\text { JICA (2010) Albania: Country Gender Profile. Tokyo. Accessed 17/07/ } \\
\text { 2015, http://gwweb.jica.go.jp/km/FSubject1501.nsf/ } \\
\text { cfe2928f2c56e150492571c7002a982c/ } \\
\text { d27d6d716f917cdc49257afe001ca92c/\$FILE/\%E8\%8B\%B1\%E8\% } \\
\text { AA\%9E\%E7\%89\%88\%202009.pdf } \\
\text { JICA (2011) Country Gender Profile: Timor-Leste. Tokyo. Accessed } \\
\text { 17/07/2015, http://www.jica.go.jp/english/our_work/thematic_ } \\
\text { issues/gender/background/pdf/e10timor.pdf }\end{array}$ \\
\hline $\begin{array}{l}\text { League of Arab } \\
\text { States }\end{array}$ & LAS & 1945 & $\begin{array}{l}\text { Regional } \\
\text { IGO }\end{array}$ & $S$ & $\begin{array}{l}\text { LAS (2008) A Plan for the Development of Education in the Arab } \\
\text { Countries. Tunis. Accessed 17/07/2015, http://www.alecso.org.tn/ } \\
\text { Ing/images/stories/fichiers/en/KHOTTA\%202008/KHOTTA\% } \\
\text { 202008\%20Eng.pdf }\end{array}$ \\
\hline $\begin{array}{l}\text { Organization for } \\
\text { Economic } \\
\text { Cooperation and } \\
\text { Development }\end{array}$ & OECD & 1960 & IGO & $\mathrm{N}$ & $\begin{array}{l}\text { OECD (1996) Lifelong Learning For All. Paris. } \\
\text { OECD (2004a) Policy Brief, Lifelong Learning. Paris. Accessed 15/07/ } \\
\text { 2015, http://www.oecd.org/education/skills-beyond-school/ } \\
\text { 29478789.pdf } \\
\text { OECD (2004b) Co-financing Lifelong Learning. Towards a systematic } \\
\text { approach.Paris. } \\
\text { OECD (2008) 21st Century Learning: Research, Innovation and Policy. } \\
\text { Directions from recent OECD analyses. Paris. Accessed 15/07/2015, } \\
\text { <http://www.oecd.org/site/educeri21st/40554299.pdf> }\end{array}$ \\
\hline $\begin{array}{l}\text { Organization of } \\
\text { American States }\end{array}$ & OAS & 1948 & $\begin{array}{l}\text { Regional } \\
\text { IGO }\end{array}$ & M & $\begin{array}{l}\text { OAS (2001) To strengthen democracy, create prosperity and realize } \\
\text { human potential, our Governments will. Quebec. Accessed 17/07/ } \\
2015 \text {, http://www.oas.org/dil/Plan_of_Action_Quebec.pdf } \\
\text { OAS (2005) Declaration of Scarborough and Commitments to Action. } \\
\text { Scarborough. Accessed 17/07/2015, } \\
\text { www.oas.org/OASpage/esp/ ... /Declaration_Scarborough_ } \\
\text { rev3_ENG.doc }\end{array}$ \\
\hline $\begin{array}{l}\text { Organization of } \\
\text { Eastern } \\
\text { Caribbean States }\end{array}$ & OECS & 1981 & $\begin{array}{l}\text { Regional } \\
\text { IGO }\end{array}$ & $S$ & $\begin{array}{l}\text { OECS (2001) Strategic Plan 2001-2010. Castries. Accessed 17/07/ } \\
\text { 2015, www.oecs.org/publications/doc_download/177-oeru- } \\
\text { strategic-plan } \\
\text { OECS (2002) Information and Communication Technology (ICT) } \\
\text { Learning Outcomes. Castries. Accessed 17/07/2015, } \\
\text { www.oecs.org/edmu-documents/doc ... /156-ict-learning- } \\
\text { outcomes } \\
\text { OECS (2007) Universal Secondary Education in the OECS: Policy and } \\
\text { Access, Quality and Rewards. Castries. Accessed 17/07/2015, } \\
\text { www.oecs.org/ ... /144-universal-secondary-education-in-the- } \\
\text { oecs-policy-and-access-quality-and-rewards-a-paper-for-discu }\end{array}$ \\
\hline $\begin{array}{l}\text { Pacific Island } \\
\text { Forum }\end{array}$ & PIF & 1971 & $\begin{array}{l}\text { Regional } \\
\text { IGO }\end{array}$ & $S$ & $\begin{array}{l}\text { PIF (2007) Non-Formal Education in Pacific Island Countries. } \\
\text { Auckland. Accessed 17/07/2015, http://www.paddle.usp.ac.fj/cgi- } \\
\text { bin/paddle?e=d-0paddle--00-1-0---0-10-TX--4-----0-111--1-en- } \\
\text { 50---20-home---00031-000-1-0utfZz-8-00\&a=file\&d=pifs029 } \\
\text { PIF (2015) Entrepreneurship Education. Apia. Accessed 17/07/2015, } \\
\text { http://www.paddle.usp.ac.fj/cgi-bin/paddle?e=d-010off-paddle-- } \\
\text { 00-1--0---0-10-TX--6------0-111--11-en-50---20-png---10-3-1- } \\
\text { 000--0-0-11-0utfZz-8-00\&a=d\&d=pifs053\&gg=1 }\end{array}$ \\
\hline Plan International & PI & 1937 & INGO & $\mathrm{N}$ & $\begin{array}{l}\text { PI (2013) Global Thematic Review. Early Childhood Care and } \\
\text { Development. Accessed 14/08/2015, }\end{array}$ \\
\hline
\end{tabular}


Table A1. Continued.

\begin{tabular}{|c|c|c|c|c|c|}
\hline Organization & Abbrev. & Found. & Type & A. & \\
\hline & & & & & $\begin{array}{l}\text { https://plan-international.org/publications/global-thematic- } \\
\text { review-early-child-care-and-development } \\
\text { PI (2014) Include us in education! A qualitative study on barriers } \\
\text { and enablers to education for children with disabilities in Nepal. } \\
\text { Executive Summary. Accessed 14/08/2015, https://plan- } \\
\text { international.org/publications/include-us-disability-inclusion- } \\
\text { education }\end{array}$ \\
\hline $\begin{array}{l}\text { Results - The } \\
\text { Power to End } \\
\text { Poverty }\end{array}$ & Results & 1980 & INGO & $\mathrm{N}$ & $\begin{array}{l}\text { Results (2015) Right to Education Index - Background Paper. } \\
\text { Accessed 14/08/2015 } \\
\text { http://www.results.org/uploads/files/RTEl_Background_ } \\
\text { Paper___April_2015.pdf }\end{array}$ \\
\hline Save the Children & $\mathrm{StC}$ & 1919 & INGO & $\mathrm{N}$ & $\begin{array}{l}\text { Moving ahead. Save the Children's Global Education Strategy to } \\
\text { 2015. Accessed 14/08/2015, } \\
\text { https://www.savethechildren.net/sites/default/files/libraries/ } \\
\text { Moving\%20ahead\%20on\%20education_Save\%20the\% } \\
\text { 20Children's\%20global\%20education\%20strategy\%20to\% } \\
\text { 202015.pdf }\end{array}$ \\
\hline $\begin{array}{l}\text { South Asian } \\
\text { Association for } \\
\text { Regional } \\
\text { Cooperation }\end{array}$ & SAARC & 1985 & $\begin{array}{l}\text { Regional } \\
\text { IGO }\end{array}$ & $S$ & $\begin{array}{l}\text { SAARC (2007) Final Report. Priority Areas of Investment in Vocational } \\
\text { Education and Skill Development in South Asia. Kathmandu. } \\
\text { Accessed 17/07/2015, http://www.shrdc.org/doc/research/study/ } \\
\text { VESD.pdf } \\
\text { SAARC (2010) Workshop Report Financing Education for Achieving } \\
\text { Education for All Goals. Islamabad. Accessed 17/07/2015, http:// } \\
\text { www.shrdc.org/doc/training/report/EFA\%202010.pdf }\end{array}$ \\
\hline $\begin{array}{l}\text { Southern African } \\
\text { Development } \\
\text { Community }\end{array}$ & SADC & 1992 & $\begin{array}{l}\text { Regional } \\
\text { IGO }\end{array}$ & $\mathrm{S}$ & $\begin{array}{l}\text { SADC (2007) Review of the Status and Capacities for the } \\
\text { Implementation of the Protocol on Education and Training. } \\
\text { Gaborone. Accessed 17/07/2015, www.che.ac.ls/ops/view/read_ } \\
\text { document.php? ... SADC ... REVIEW\%20(2) ... }\end{array}$ \\
\hline $\begin{array}{l}\text { Stichting } \\
\text { Nederlandse } \\
\text { Vrijwilligers }\end{array}$ & SNV & 1965 & Agency & $\mathrm{N}$ & $\begin{array}{l}\text { SNV (2007) Dangme West District and Quality Education. The Hague. } \\
\text { Accessed 17/07/2015, http://www.snvworld.org/sites/www. } \\
\text { snvworld.org/files/publications/our_children_our_future.pdf }\end{array}$ \\
\hline $\begin{array}{l}\text { United Nations } \\
\text { Childreńs Fund }\end{array}$ & UNICEF & 1946 & IGO & G & $\begin{array}{l}\text { UNICEF (2003) Report. Sport for development and peace: Towards } \\
\text { achieving the millennium development goals. New York. Accessed } \\
\text { 15/07/2015, http://www.un.org/wcm/webdav/site/sport/shared/ } \\
\text { sport/pdfs/Reports/2003_interagency_report_ENGLISH.pdf } \\
\text { UNICEF (2012) Climate Change Adaptation and Disaster Risk } \\
\text { Reduction in the Education Sector. New York. Accessed 15/07/ } \\
\text { 2015, http://www.unicef.org/education/files/UNICEF- } \\
\text { ClimateChange-ResourceManual-lores-c.pdf }\end{array}$ \\
\hline $\begin{array}{l}\text { United Nations } \\
\text { Educational, } \\
\text { Scientific and } \\
\text { Cultural } \\
\text { Organization }\end{array}$ & UNESCO & 1945 & IGO & G & $\begin{array}{l}\text { UNESCO (1990) Final report, World Conference on Education for All: } \\
\text { Meeting Basic Learning Needs. Jomtien. Accessed 15/07/2013, } \\
\text { http://unesdoc.unesco.org/images/0009/000975/097551e.pdf } \\
\text { UNESCO (1996) Report, Learning the Treasure Within. Paris. Accessed } \\
\text { 15/07/2015, http://unesdoc.unesco.org/images/0010/001095/ } \\
\text { 109590eo.pdf } \\
\text { UNESCO (2000) The Dakar Framework for Action. Dakar. Accessed } \\
\text { 15/07/2015, http://unesdoc.unesco.org/images/0012/001211/ } \\
\text { 121147e.pdf } \\
\text { UNESCO (2001) Technical and Vocational Education an Training for } \\
\text { the Twenty first Century. Paris. Accessed 15/07/2015, } \\
\text { http://unesdoc.unesco.org/images/0012/001260/126050e.pdf } \\
\text { UNESCO (2007a) Report, Strong foundations. Early childhood care } \\
\text { and education. Paris. Accessed 15/07/2015, http://unesdoc. } \\
\text { unesco.org/images/0014/001477/147794e.pdf } \\
\text { UNESCO (2007b) Report, Strong foundations. Early childhood care } \\
\text { and education. Paris. Accessed 15/07/2015, http://unesdoc. } \\
\text { unesco.org/images/0014/001477/147794e.pdf } \\
\text { UNESCO (2008) Jakarta Strategy Paper on South-South Policy Forum, } \\
\text { on Lifelong Learning as the key to Sustainable Development. } \\
\text { Jakarta. Accessed 15/07/2015, http://uil.unesco.org/fileadmin/ } \\
\text { keydocuments/LifelongLearning/en/Jakarta-s-forum-paper.pdf } \\
\text { UNESCO (2009) Final report, confintea VI, sixth international } \\
\text { conference on adult education. Hamburg. Accessed 15/07/2015, }\end{array}$ \\
\hline
\end{tabular}


Table A1. Continued.

\begin{tabular}{|c|c|c|c|c|c|}
\hline Organization & Abbrev. & Found. & Type & A. & \\
\hline & & & & & $\begin{array}{l}\text { http://unesdoc.unesco.org/images/0018/001877/187790e.pdf } \\
\text { UNESCO (2010) Report, Reaching the marginalized. Paris. Accessed } \\
\text { 15/07/2015, http://unesdoc.unesco.org/images/0018/001866/ } \\
\text { 186606E.pdf } \\
\text { UNESCO (2011) UNESCO and "Everyone has the right to education". } \\
\text { Paris. Accessed 15/07/2015, http://unesdoc.unesco.org/images/ } \\
\text { 0021/002127/212715e.pdf }\end{array}$ \\
\hline $\begin{array}{l}\text { United States } \\
\text { Agency for } \\
\text { International }\end{array}$ & USAID & 1961 & Agency & $\mathrm{N}$ & $\begin{array}{l}\text { USAID (2007) Final Evaluation. Managing Basic Education (MBE) } \\
\text { Project. Washington DC. Accessed 17/07/2015, mbeproject.net/ } \\
\text { evaluation-e.doc }\end{array}$ \\
\hline Development & & & & & $\begin{array}{l}\text { USAID (2011) Hope Arrives on Two Wheels in Hirat. Hirat. Accessed } \\
\text { 17/07/2015, http://www.fukuoka.unhabitat.org/projects/voices/ } \\
\text { afghanistan/pdf/Success_Story_Herat_June_2011.pdf }\end{array}$ \\
\hline $\begin{array}{l}\text { Voluntary Service } \\
\text { Overseas }\end{array}$ & VSO & 1958 & INGO & $\mathrm{N}$ & $\begin{array}{l}\text { VSO (2015) Meta-evaluation and Synthesis Report. Accessed 14/08/ } \\
\text { 2015, https://www.vsointernational.org/sites/default/files/VSO\% } \\
\text { 20Meta-evaluation\%20and\%20Synthesis\%20Review\%20Report } \\
\text { \%20-\%20July\%202016.pdf }\end{array}$ \\
\hline World Bank & WB & 1945 & IGO & G & $\begin{array}{l}\text { World Bank (1999) Education Sector Strategy. Washington DC. } \\
\text { Accessed 15/07/2015, http://siteresources.worldbank.org/ } \\
\text { EDUCATION/Resources/ESSU/education_strategy_1999.pdf } \\
\text { World Bank (2003a) Education and HIV/Aids. A Window of Hope. } \\
\text { Washington DC. Accessed 16/07/2015, http://siteresources. } \\
\text { worldbank.org/EDUCATION/Resources/278200-1099079877269/ } \\
\text { 547664-1099080042112/Edu_HIVAIDS_window_hope.pdf } \\
\text { World Bank (2003b) Lifelong Learning in the Globaal Knowledge } \\
\text { Economy. Challenges for Developing Countries. Washington DC. } \\
\text { Accessed 16/07/2015, http://siteresources.worldbank.org/INTLL/ } \\
\text { Resources/Lifelong-Learning-in-the-Global-Knowledge- } \\
\text { Economy/lifelonglearning_GKE.pdf } \\
\text { World Bank (2011) Learning for All: Investing in People's Knowledge } \\
\text { and Skills to Promote Development. Washington DC. Accessed 16/ } \\
\text { 07/2015, http://siteresources.worldbank.org/EDUCATION/ } \\
\text { Resources/ESSU/Education_Strategy_4_12_2011.pdf } \\
\text { World Bank (2013) World Development Report 2013. Washington } \\
\text { DC. Accessed 16/07/2013, <<http://siteresources.worldbank.org/ } \\
\text { EXTNWDR2013/Resources/8258024-1320950747192/8260293- } \\
\text { 1322665883147/WDR_2013_Report.pdf >> } \\
\text { World Bank (2015) World Development Report 2015. Washington } \\
\text { DC. Accessed 16/07/2015, http://siteresources.worldbank.org/ } \\
\text { EXTNWDR2015/Resources/8258024-1320950747192/8260293- } \\
\text { 1322665883147/WDR_2015_Report.pdf }\end{array}$ \\
\hline $\begin{array}{l}\text { World Health } \\
\text { Organization }\end{array}$ & WHO & 1948 & IGO & G & $\begin{array}{l}\text { WHO (1998) The World Health Report 1998. Life in the 21st century. A } \\
\text { vision for all. Geneva. Accessed 16/07/2015, } \\
\text { http://www.who.int/whr/1998/en/whr98_en.pdf } \\
\text { WHO (2007) Information, Malaria Prevention and Control: An } \\
\text { important responsibility of a Health-Promoting School. Geneva. } \\
\text { Accessed 16/07/2015, http://www.who.int/chp/topics/ } \\
\text { healthpromotion/MALARIA_FINAL.pdf }\end{array}$ \\
\hline
\end{tabular}

\section{Note: $\mathbf{N}=42$}

Types:

IGO = Intergovernmental organizations $(\mathrm{N}=8)$

Regional IGO = Regional intergovernmental organizations $(\mathrm{N}=16)$

Banks = Regional and financial intergovernmental organizations $(\mathrm{N}=5)$

Agency = Bilateral internationally-oriented national organizations $(\mathrm{N}=6)$

INGO = International nongovernmental organizations ( $\mathrm{N}=7$ )

\section{Areas:}

$\mathrm{N}=$ North $(\mathrm{N}=16)$

$\mathrm{S}=$ South $(\mathrm{N}=15)$

$\mathrm{G}=$ Global $(\mathrm{N}=8)$

$\mathrm{M}=\operatorname{Mixed}(\mathrm{N}=3)$ 
Table A2. Coding system.

\begin{tabular}{|c|c|c|c|c|}
\hline Sub-Categories & Concepts & $\underset{n=42)}{N(\%)}$ & Organisations' references & Coding examples \\
\hline \multirow[t]{5}{*}{ students } & $\begin{array}{l}\text { non-specified } \\
\text { individual } \\
\text { learner }\end{array}$ & 42 & all (see A.1) & $\begin{array}{l}\text { preparation and empowerment of the } \\
\text { learner to master the tools of } \\
\text { knowledge and build an all-able } \\
\text { personality }\end{array}$ \\
\hline & $\begin{array}{l}\text { by non-specified } \\
\text { 'marginalized' }\end{array}$ & 31 & $\begin{array}{l}\text { ECOSOC (2011:5); ILO (2003a:1); } \\
\text { IMF (2006:78); UNICEF } \\
\text { (2011:7); OECD (2004c:34); } \\
\text { WB (2003b:71); UNESCO } \\
\text { (2000:27) - APEC (2010b:51); } \\
\text { ASEAN (2009:68); CAN } \\
\text { (2004:18); CoE (2008:18); CoL } \\
\text { (2012a:19); ECOWAS 2009:1); } \\
\text { EU (2012:4); EURASEC (2008: } \\
\text { APPENDIX II-2); LAS } \\
\text { (2008:158); OAS (2001:27); } \\
\text { SAARC (2010b:23) - ADB } \\
\text { (2009: 19); AFDB (2007b:16); } \\
\text { IADB (2009:1); IDB (2006: 4) - } \\
\text { AECID (2006:1); AFD (no } \\
\text { date:1); DFID (2011b); } \\
\text { EuropeAid (2010:158); GIZ } \\
\text { (2012b:7); USAID (2005:5f.) - } \\
\text { ICFTU (2004:6); IMWF } \\
\text { (2005b:15); UNI (2009:13); } \\
\text { BIAC (2001:4); ICC (2012:5); } \\
\text { UEAPME (2002a:1); EPSU } \\
\text { (2011:7) }\end{array}$ & $\begin{array}{l}\text { people with special needs (learning } \\
\text { disabilities), internally displaced } \\
\text { persons, people with HIV/ AIDS; } \\
\text { refugees; children under constant } \\
\text { care; street and working children, } \\
\text { nomadic communities, children in } \\
\text { remote environments and areas of } \\
\text { conflict, minority groups, }\end{array}$ \\
\hline & by age & 22 & $\begin{array}{l}\text { ECOSOC (2011:5); ILO (2003a:1); } \\
\text { IMF (2006:78); UNICEF } \\
\text { (2011:7); OECD (2004c:14); } \\
\text { WB ( 2000:33); UNESCO } \\
\text { (2000:27) - AU (2006:8); CAN } \\
\text { (2004:18); EU (2012); LAS } \\
\text { (2008:124); OAS (2001:27); } \\
\text { SAARC (2010b:23) - AFDB } \\
\text { (2007b:16); CoEDB (2006:8); } \\
\text { IADB (2009:1) - JICA } \\
\text { (2007:19) - ICFTU (2000:192); } \\
\text { UNI (2009:13); AAI (2011:7); }\end{array}$ & $\begin{array}{l}\text { the unborn/ in utero; Children (starting } \\
\text { from } 2 \text { years of age); the young; } \\
\text { adults; the elderly; senior citizens }\end{array}$ \\
\hline & $\begin{array}{l}\text { by socio- } \\
\text { economic } \\
\text { status }\end{array}$ & 21 & $\begin{array}{l}\text { ILO (2003a:1); UNICEF (2011:7); } \\
\text { WB (2003b:14); UNESCO } \\
\text { (2012:100) - AU (2012:7); } \\
\text { CAN (2004:18); CoL } \\
\text { (2012b:14); ECOWAS 2009:1); } \\
\text { OAS (2001:27) - ADB (2009: } \\
\text { 19); AFDB (2007c:19); CoEDB } \\
\text { (2006:8); EBRD (2008:81); } \\
\text { IADB (2009:1); IDB (2006: 4) - } \\
\text { AFD (2006:7); GIZ (2012a:12) } \\
\text { - EPSU (2011:20); AA1 } \\
\text { (2011:4); }\end{array}$ & $\begin{array}{l}\text { unemployed, underemployed, } \\
\text { employed (employees); workers; } \\
\text { informal economy workers, service } \\
\text { industry workers; traditional } \\
\text { economy workers; }\end{array}$ \\
\hline & by gender & 19 & $\begin{array}{l}\text { ILO (2003a:1); WB (2003b:14); } \\
\text { UNESCO (2010a:43) - APEC } \\
\text { (2009:39); CAN (2004:18); CoL } \\
\text { (2012a:19); EU (2007b:104); } \\
\text { OAS (2001:27) - ADB (2009: } \\
\text { 19) - AECID (2006:1); AFD (no }\end{array}$ & $\begin{array}{l}\text { Girls; women; con perspectiva de } \\
\text { género; with gender concerns; } \\
\text { l'équité dans cet accès (filles et } \\
\text { garçons, ruraux et urbains) }\end{array}$ \\
\hline
\end{tabular}


Table A2. Continued.

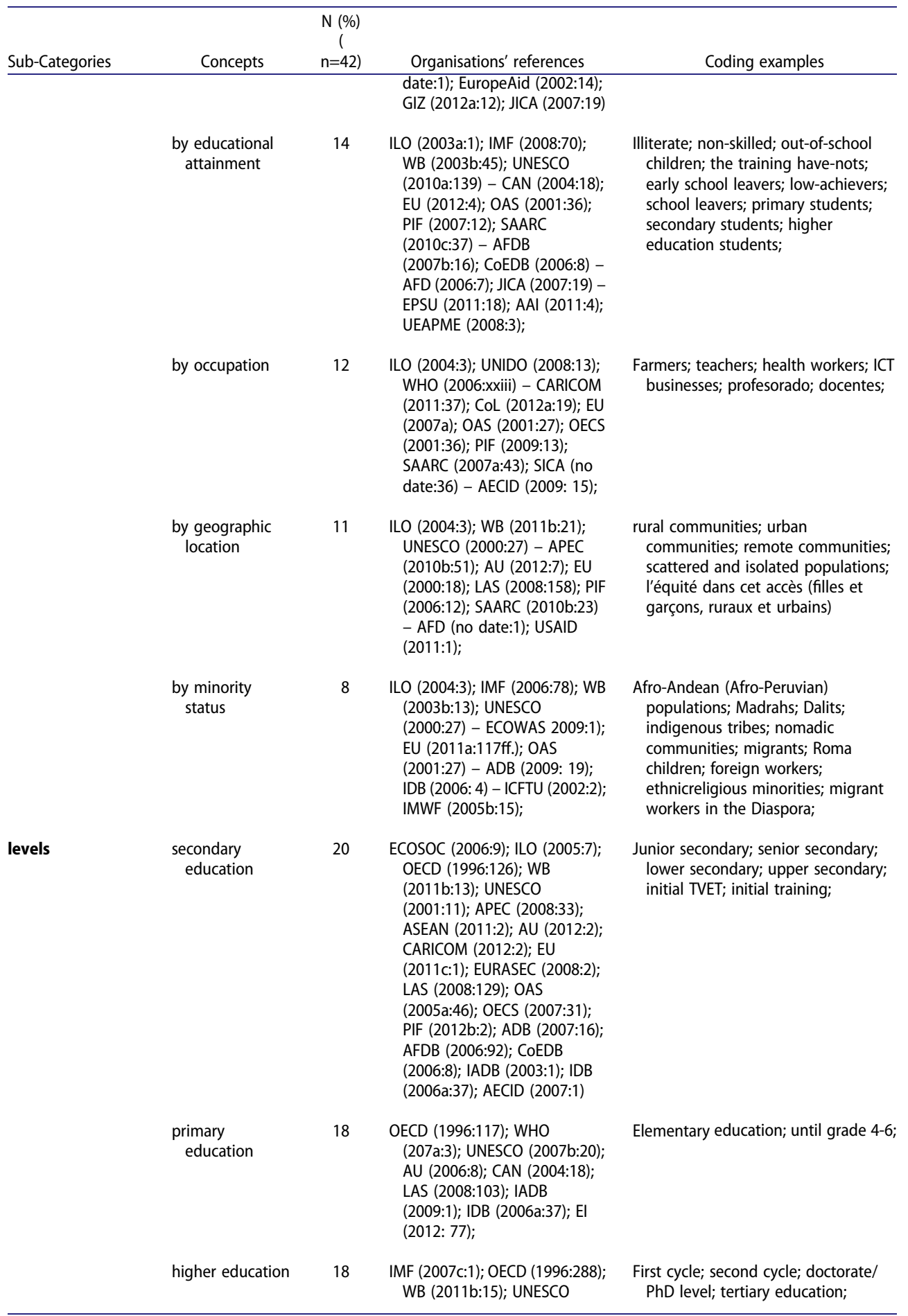

(Continued) 
Table A2. Continued.

\begin{tabular}{|c|c|c|c|c|}
\hline & Concepts & $\begin{array}{c}\mathrm{N}(\%) \\
( \\
\mathrm{n}=42)\end{array}$ & Organisations' references & Coding examples \\
\hline \multirow{3}{*}{ Sub-Categories } & & & $\begin{array}{l}\text { (2004:8); APEC (2011:7); } \\
\text { CARICOM (2012:2); CoE } \\
\text { (2008:18); EU (2011a:31); LAS } \\
\text { (2008:155); UFM (2012:1); } \\
\text { AFDB (2004: 17); IDB (no } \\
\text { date:1); AAI (2011:4); }\end{array}$ & \\
\hline & $\begin{array}{l}\text { early childhood } \\
\text { education }\end{array}$ & 18 & $\begin{array}{l}\text { ECOSOC (2011:5); IMF } \\
\text { (2006:78); OECD (1996:121); } \\
\text { UNICEF (2011:7); UNESCO } \\
\text { (2007a:65); WB (2000:33); EU } \\
\text { (2011a:31); PIF (2009:6); AFDB } \\
\text { (2007a:6); IADB (2009:1); } \\
\text { EuropeAid (2010:26); BSEC } \\
\text { (2007: APPENDIX II-1); LAS } \\
\text { (2008:94); AFDB (2007a:6); } \\
\text { IADB (2009:1) }\end{array}$ & $\begin{array}{l}\text { Pre-primary education; kindergarten; } \\
\text { from } 2 \text { years on; }\end{array}$ \\
\hline & further education & 8 & $\begin{array}{l}\text { ILO (2004:3); IMF (2009:41); } \\
\text { UNIDO (2007:22); OECD } \\
\text { (1996:148); WB (2011b:13); } \\
\text { WHO (2006:xxiii); WTO } \\
\text { (2007b:7); UNESCO (2001:9); } \\
\text { ASEAN (2010:81); BSEC (2007: } \\
\text { APPENDIX II-1); CAN (2008:1); } \\
\text { CARICOM (2012:2); CoL } \\
\text { (2012b:14); EAC (2009:35); } \\
\text { ECOWAS (2009:1); EU } \\
\text { (2011b:11); LAS (2008:119); } \\
\text { OAS (2005a:46); PIF (2009:12); } \\
\text { SAARC (2007b:54); SADC } \\
\text { (2007:57); SICA (no date:36); } \\
\text { ADB (2209:19); AFDB } \\
\text { (2007c:19); CoEDb (2006:8); } \\
\text { EBRD (2008:61); AECID } \\
\text { (2007:1) -EI (2012: 12); }\end{array}$ & $\begin{array}{l}\text { Further education; continuing } \\
\text { education; adult TVEDT; adult } \\
\text { training; professional education ; } \\
\text { union education; formación } \\
\text { ocupacional; }\end{array}$ \\
\hline \multicolumn{5}{|l|}{$\begin{array}{l}\text { core category: } \\
\text { goals }\end{array}$} \\
\hline $\begin{array}{l}\text { curricular } \\
\text { goals }\end{array}$ & $\begin{array}{l}\text { individual: } \\
\text { empowerment }\end{array}$ & 39 & $\begin{array}{l}\text { ECOSOC (2006:8); ILO } \\
\text { (2013:509); IMF (2012b:93); } \\
\text { UNESCO (2011b:34); UNICEF } \\
\text { (2011:26); UNIDO (2008:17); } \\
\text { WB (2003b:58); WHO } \\
\text { (2007:36) - APEC (1999:3); } \\
\text { ASEAN (2009:75); AU (2006:2); } \\
\text { CARICOM (2011:37); CoL } \\
\text { (2012a:17); EAC (2009:66); EU } \\
\text { (2011a:127); EURASEC } \\
\text { (2008:2); LAS (2008:32); PIF } \\
\text { (2012b:3); SARC (2010c:21); } \\
\text { SADC (2007:80); OAS } \\
\text { (2001:34); OECS (2007:24) - } \\
\text { ADB (2009:70); AFDB } \\
\text { (2008b:1); IADB (2013:1); IDB } \\
\text { (2006a:33) - AECID (no } \\
\text { date:16); AFD (2006:19); DFID } \\
\text { (2011c:13); EuropeAid } \\
\text { (2010b:176); GIZ (2012a:25); } \\
\text { JICA (2011b:24); SNV (2012:5); }\end{array}$ & $\begin{array}{l}\text { Women's economic empowerment; } \\
\text { economic empowerment; children's } \\
\text { empowerment; social } \\
\text { empowerment; capacitación; } \\
\text { motiver les individus à s'engager } \\
\text { dans la responsabilisation de leur } \\
\text { parcours d'insertion et de } \\
\text { professionnalisation; maîtrise de son } \\
\text { avenir professionnel; empowerment } \\
\text { of individuals; }\end{array}$ \\
\hline
\end{tabular}


Table A2. Continued.

\begin{tabular}{|c|c|c|c|c|}
\hline \multirow{3}{*}{\multicolumn{2}{|c|}{ Sub-Categories }} & \multirow[t]{2}{*}{$\begin{array}{l}N(\%) \\
n=42)\end{array}$} & \multirow{2}{*}{$\begin{array}{l}\text { Organisations' references } \\
\text { USAID (2011:1) - El (2012:46); } \\
\text { AAI (2011:1) }\end{array}$} & \multirow[t]{2}{*}{ Coding examples } \\
\hline & & & & \\
\hline & & 26 & $\begin{array}{l}\text { ILO (2000:2); IMF (2006:78); } \\
\text { UNICEF (2011:7); UNIDO } \\
\text { (2007:15); OECD (1996:40); } \\
\text { WB (2011b:54); WHO } \\
\text { (1998:207); WTO (2007b:7); } \\
\text { UNESCO (2000:18) - EAC } \\
\text { (2009:35); ECOWAS (2009:1); } \\
\text { EU (1995b:1); LAS (2008:165); } \\
\text { OAS (2001:29); OECS (2002:8); } \\
\text { SAARC (2007 :1) - ADB (2007: } \\
\text { 16); AFDB (2007c:19); CoEDB } \\
\text { (2012a:19); EBRD (2008:61); } \\
\text { IADB (2009:1); IDB } \\
\text { (2006a:37f.) - AFD (no date } \\
\text { a:1); DFID (2011c:4); } \\
\text { EuropeAld (2002:6); GIZ } \\
\text { (2011c:1); SNV (2007:12); } \\
\text { USAID (2003:61) }\end{array}$ & $\begin{array}{l}\text { Economic growth; economic progress; } \\
\text { economic development; economic } \\
\text { prosperity; productivity; ; } \\
\text { competitiveness; adaptability of the } \\
\text { workforce; full employment; formal } \\
\text { economy; knowledge for economy; }\end{array}$ \\
\hline & $\begin{array}{l}\text { individual: } \\
\text { capabilities }\end{array}$ & 20 & $\begin{array}{l}\text { ECOSOC (2011:12); ILO (2004:1); } \\
\text { IMF (2012b:74); UNICEF } \\
\text { (2011:7); UNESCO (2011a:5); } \\
\text { WB (2003a:56) - APEC } \\
\text { (2004:1); ASEAN (2009:68); EU } \\
\text { (2011a:123); LAS (2008:7); } \\
\text { OAS (2001:29); SAARC } \\
\text { (2007b:69); OECS (2000:44) - } \\
\text { AFDB (2004:1); ADB (2009:67); } \\
\text { IDB (2006a:30) - DFID } \\
\text { (2011b:20) - EuropeAid } \\
\text { (2010b:6); USAID (2003:23); }\end{array}$ & $\begin{array}{l}\text { Employability; improve career } \\
\text { opportunities; higher earnings; } \\
\text { programs for skills' management } \\
\text { and lifelong learning that support } \\
\text { continued employability; }\end{array}$ \\
\hline & $\begin{array}{l}\text { collective: social } \\
\text { cohesion }\end{array}$ & 19 & $\begin{array}{l}\text { ILO (2000:2); IMF (2008:69); } \\
\text { OECD (2004c:4); UNESCO } \\
\text { (2010a:78); UNICEF (2011:7); } \\
\text { WHO (2001:40); WB } \\
\text { (2011b:25) - APEC (2004:7); } \\
\text { EU (2005:73); PIF (2009:6); } \\
\text { SAARC (2010a:14); SADC } \\
\text { (2007:29); OAS (2001:29) - } \\
\text { ADB (2009:71); AFDB } \\
\text { (2007a:5); IADB (2009:1) - } \\
\text { EuropeAid (2010c:12); USAID } \\
\text { (2006:1) - El (2009:1); }\end{array}$ & $\begin{array}{l}\text { Equity; equality; integration into } \\
\text { national societies and world society; }\end{array}$ \\
\hline & collective: values & 13 & $\begin{array}{l}\text { IMF (2012b:74); UNESCO } \\
\text { (2000:65); OECD (1996:103) - } \\
\text { AU (2006:8); CAN (2008:1f.); } \\
\text { CARICOM (2009:1); CoE } \\
\text { (2007:2); EU ( 1995b:11; } \\
\text { 2011a:128); EURASEC (2008: } \\
\text { APPENDIX II-2); LAS (2008:9); } \\
\text { OAS (2001:30); }\end{array}$ & $\begin{array}{l}\text { Tolerance; democracy; Democratic } \\
\text { norms, values and structures; }\end{array}$ \\
\hline & $\begin{array}{l}\text { individual: } \\
\text { identity }\end{array}$ & 11 & $\begin{array}{l}\text { OECD (1996:121); UNESCo } \\
\text { (2011a:23); AU (2006:8); } \\
\text { ASEAN (2011:3); EU (2005:58); } \\
\text { LAS (2008:40 \& 182); OAS } \\
\text { (2012:79); }\end{array}$ & $\begin{array}{l}\text { being a world citizen; education for } \\
\text { global citizenship; }\end{array}$ \\
\hline & $\begin{array}{l}\text { individual: } \\
\text { personal } \\
\text { development }\end{array}$ & 11 & $\begin{array}{l}\text { OECD (2007b:10); UNESCO } \\
\text { (2008:3); UNICEF (2011:30); } \\
\text { WB (2003b:96); WHO } \\
\text { (2007:34) - APEC (1999:213); }\end{array}$ & $\begin{array}{l}\text { realize full potential; personal } \\
\text { transformation; personal fulfilment; } \\
\text { well-being; }\end{array}$ \\
\hline
\end{tabular}

(Continued) 
Table A2. Continued.

\begin{tabular}{|c|c|c|c|c|}
\hline Sub-Categories & Concepts & $\begin{array}{l}N(\%) \\
n=42)\end{array}$ & Organisations' references & Coding examples \\
\hline & & & $\begin{array}{l}\text { EU (2011b:12); PIF (2007:15); } \\
\text { SAARC (2012a:52); SADC } \\
\text { (2007:15); OAS (2005:57); } \\
\text { OECS (2012:39) - EuropeAid } \\
\text { (2010b:159); SNV (2007:27) }\end{array}$ & \\
\hline & $\begin{array}{l}\text { individual: } \\
\text { employability }\end{array}$ & 9 & $\begin{array}{l}\text { ECOSOC (2006:9); ILO (2004:2); } \\
\text { OECD (2007a:6); UNIDO } \\
\text { (2007:15); UESCO ((2012:28); } \\
\text { WB (2012:36) - APEC } \\
\text { (2004:3); EU (2012:6); OAS } \\
\text { (2001:30) - CoEDB } \\
\text { (2012b:31); EBRD (2011:5) - } \\
\text { DFID (2011c:4); EuropeAid } \\
\text { (2006:2) }\end{array}$ & $\begin{array}{l}\text { Employability can best be defined as } \\
\text { 'possession of qualities and } \\
\text { competences to meet the ever- } \\
\text { changing needs of the market and } \\
\text { the organisation, as well as the pace } \\
\text { of technological change; }\end{array}$ \\
\hline \multicolumn{5}{|l|}{$\begin{array}{l}\text { core category: } \\
\text { curriculum } \\
\text { content and } \\
\text { competences }\end{array}$} \\
\hline subjects & $\begin{array}{l}\text { human rights/ } \\
\text { citizenship }\end{array}$ & 14 & $\begin{array}{l}\text { IMF (2012b:74); UNESCO } \\
\text { (2000:65); OECD (1996:103) - } \\
\text { AU (2006:8); CAN (2008:1f.); } \\
\text { CoE (2007:2); EU (2011a:128); } \\
\text { EURASEC (2008:APPENDIX II- } \\
\text { 2); LAS (2008:9); OAS } \\
\text { (2001:30); }\end{array}$ & $\begin{array}{l}\text { Civic education; peace; civic } \\
\text { responsibility; intercultural } \\
\text { understanding/ competence; }\end{array}$ \\
\hline & vocational & 11 & $\begin{array}{l}\text { ILO (2005:7); IMF (2006:78); } \\
\text { UNIDO (2008:13); WB } \\
\text { (2011b:13); OECD (1996:88); } \\
\text { WHO (2006:82); WTO } \\
\text { (2007b:7) - APEC (2004:1f.); } \\
\text { ASEAN (2009:68); AU (2012:2); } \\
\text { CAN 1999: 17); }\end{array}$ & $\begin{array}{l}\text { further education; lifelong learning; } \\
\text { training; lifelong education. }\end{array}$ \\
\hline & $\begin{array}{l}\text { foreign } \\
\text { languages }\end{array}$ & 7 & $\begin{array}{l}\text { OECD (1996:121); WTO } \\
\text { (2007b:7) - ASEAN (2009:68); } \\
\text { CoE (2007:2); EU (1995a:1) - } \\
\text { IADB (2009:1); }\end{array}$ & $\begin{array}{l}\text { higher status to minority languages } \\
\text { (e.g. Romani); business English; } \\
\text { proficiency in three European } \\
\text { languages; }\end{array}$ \\
\hline & environment & 6 & $\begin{array}{l}\text { UNIDO (2011:41); UNESCO } \\
\text { (2009:43) - CoL (2006:2); EU } \\
\text { (2010a:2); EURASEC (2008: } \\
\text { APPENDIX II-2); }\end{array}$ & $\begin{array}{l}\text { Resource efficiency; concepts of } \\
\text { nature; }\end{array}$ \\
\hline & $\begin{array}{l}\text { social studies/ } \\
\text { history }\end{array}$ & 5 & $\begin{array}{l}\text { OECD (1996:121) - AU (2006:8); } \\
\text { EU (2005:58); LAS (2008:81); }\end{array}$ & $\begin{array}{l}\text { common sense of history and cultural } \\
\text { identity; understanding/ } \\
\text { appreciation of larger society/ civic } \\
\text { order; cultural, civic and economic } \\
\text { studies; }\end{array}$ \\
\hline & humanities & 5 & $\begin{array}{l}\text { OECD (1996: 103) - APEC } \\
\text { (2012:84); EU (2011a:128) - } \\
\text { IDB (2006a: 37); }\end{array}$ & Arts; literature; \\
\hline & sciences & 5 & $\begin{array}{l}\text { OECD (1996:103) - EU } \\
\text { (2002:22); LAS (2008:7) - IDB } \\
\text { (2006a:37); }\end{array}$ & $\begin{array}{l}\text { mathematical-analytical skills and their } \\
\text { applications; scientific ways of } \\
\text { mastering and applying } \\
\text { technological knowledge; } \\
\text { information and communication } \\
\text { science; }\end{array}$ \\
\hline & $\begin{array}{l}\text { traditional } \\
\text { knowledge }\end{array}$ & 4 & $\begin{array}{l}\text { UNICEF (2000:30 and 2012:3) - } \\
\text { AU (2006:8); OAS (2001:36 } \\
\text { and 2007:30); }\end{array}$ & $\begin{array}{l}\text { Local knowledge; indigenous } \\
\text { languages and knowledge systems; } \\
\text { ethnoeducación; ethno-education; }\end{array}$ \\
\hline & $\begin{array}{l}\text { subject area: } \\
\text { religion }\end{array}$ & 2 & LAS (2008:40) - IDB (2006a:45); & $\begin{array}{l}\text { Right knowledge consists of both } \\
\text { knowledge of the religion and } \\
\text { knowledge for worldly } \\
\text { advancement. }\end{array}$ \\
\hline
\end{tabular}

(Continued) 
Table A2. Continued.

\begin{tabular}{|c|c|c|c|c|}
\hline Sub-Categories & Concepts & $\begin{array}{c}\mathrm{N}(\%) \\
\mathrm{n}=42)\end{array}$ & Organisations' references & Coding examples \\
\hline \multirow[t]{3}{*}{ competences } & basic skills & 23 & $\begin{array}{l}\text { ILO (2000:2); UNICEF (2012:3); } \\
\text { WB (2003:21); OECD } \\
\text { (1996:121); UNESCO (2000:31) } \\
\text { - CAN (1999:14); EURASEC } \\
\text { (2008:APPENDIX II-2); LAS } \\
\text { (2008:32); OAS (2005a:67); PIF } \\
\text { (2007:3); SAARC (2010c:21) - } \\
\text { ADB (no date:2); AFD (2006: } \\
\text { 9); DFID 2(004:6) - EuropeAid } \\
\text { (2002: 22); JICA (2007:19); } \\
\text { SNV (2010: 27); USAID (2003: } \\
\text { 61) -AAI (2011:4); }\end{array}$ & $\begin{array}{l}\text { Literacy; numeracy; neo-literacy; } \\
\text { éducation de base; les compétences } \\
\text { nécessaires à un apprentissage tout } \\
\text { au long de la vie et acquérir une } \\
\text { alphabétisation; }\end{array}$ \\
\hline & $\begin{array}{l}\text { cross-curriculum } \\
\text { competences }\end{array}$ & 19 & $\begin{array}{l}\text { ECOSOC (2011:5); UNICEF } \\
\text { (2011:7); WB (2013:88); OECD } \\
\text { (1996:121); UNESCO (2001:11) } \\
\text { - EU (2007c:8); LAS (2008:78); } \\
\text { OECS (2007:17); PIF (2009:5) - } \\
\text { IDB (2006a: 37); EuropeAid } \\
\text { (2010b:115); GIZ (2011c:1); } \\
\text { SNV (2010: 27) - El (2012:78); } \\
\text { AAI (2011:3); }\end{array}$ & $\begin{array}{l}\text { Cognitive, social, lingustic skills; verbal } \\
\text { ability, working memory, numeracy, } \\
\text { and problem-solving abilities; } \\
\text { reasoning; critical thinking; } \\
\text { creativity; resilient; critical; self- } \\
\text { awareness; assertiveness }\end{array}$ \\
\hline & life skills & 11 & $\begin{array}{l}\text { IMF (2012b:74); OECD } \\
\text { (1996:103); UNESCO (2009:43) } \\
\text { - AU (2006:8); CoL (2006:2); } \\
\text { SAARC (2010c:10) - ADB } \\
\text { (2009:73) - JICA (2007:19); }\end{array}$ & $\begin{array}{l}\text { Health; maternal health; reproductive } \\
\text { health; HIV/AIDS/STI; }\end{array}$ \\
\hline \multicolumn{5}{|l|}{$\begin{array}{l}\text { core category: } \\
\text { teaching and } \\
\text { learning }\end{array}$} \\
\hline \multirow[t]{4}{*}{ methods } & ICT & 19 & $\begin{array}{l}\text { OECD (1996:105); WB (2003:58); } \\
\text { UNESCO (2004:8) - APEC } \\
\text { (2010b); ASEAN (2008:68); AU } \\
\text { (2006:8); CARICOM (2011:10); } \\
\text { CoL (2012a:19); EAC } \\
\text { (2009:35); EU (2000:18); LAS } \\
\text { (2007:19); OAS (2012:27); } \\
\text { OECS (2002:17); PIF (2012:3); } \\
\text { SAARC (2010b:23); SADC } \\
\text { (2007:57); UfM (2012:1) - } \\
\text { AFDB (2004:8); IADB } \\
\text { (2013b:1); IDB (2006:31) - } \\
\text { AECID (b:18) }\end{array}$ & $\begin{array}{l}\text { Virtual universities; technology- } \\
\text { supported delivery; blended } \\
\text { learning; implemented within the } \\
\text { company, access is greatly } \\
\text { facilitated; }\end{array}$ \\
\hline & $\begin{array}{l}\text { learner-centered } \\
\text { learning }\end{array}$ & 10 & $\begin{array}{l}\text { ECOSOC (2011:13); UNICEF } \\
\text { (2012:8); OECD (2008:3); WB } \\
\text { (2003:58); WHO (2006:82); } \\
\text { UNESCO (2012:133) - CoE } \\
\text { (2007:11); EU (2001:12); LAS } \\
\text { (2007:31); PIF (2007:4) - GIZ } \\
\text { (2011c:1). }\end{array}$ & $\begin{array}{l}\text { Personalized; customized; child- } \\
\text { centred; individual demand-led; } \\
\text { individualized; tailored to interests } \\
\text { and needs; }\end{array}$ \\
\hline & $\begin{array}{l}\text { conceptual, } \\
\text { contextual } \\
\text { learning }\end{array}$ & 6 & $\begin{array}{l}\text { OECD (2008:2) - EU (2007c); } \\
\text { LAS (2007:32); OECS } \\
\text { (2007:17); SAARC (2007a:44); }\end{array}$ & $\begin{array}{l}\text { Transversal skills; key competences; } \\
\text { reduce the importance of cramming } \\
\text { the educational curriculum with } \\
\text { subject matters and details; transfer; } \\
\text { merging general education and } \\
\text { TVET; }\end{array}$ \\
\hline & $\begin{array}{l}\text { collaborative, } \\
\text { experiential } \\
\text { learning }\end{array}$ & 5 & $\begin{array}{l}\text { UNICEF (2012:3); OECD (2008:2); } \\
\text { UNESCO (2012:133) - EU } \\
\text { (2000:17); }\end{array}$ & $\begin{array}{l}\text { Participatory; group-based; interactive; } \\
\text { communicative; action-based; } \\
\text { accreditation of prior and } \\
\text { experiential learning }\end{array}$ \\
\hline $\begin{array}{l}\text { learning } \\
\text { environment }\end{array}$ & $\begin{array}{l}\text { new role for } \\
\text { teachers }\end{array}$ & 18 & $\begin{array}{l}\text { ILO (2000a:2); OECD (2008:6); } \\
\text { UNESCO (2009:77); UNICEF }\end{array}$ & $\begin{array}{l}\text { Motivating students to continue } \\
\text { learning throughout life should be }\end{array}$ \\
\hline
\end{tabular}


Table A2. Continued.

\begin{tabular}{|c|c|c|c|c|}
\hline \multirow[t]{3}{*}{ Sub-Categories } & Concepts & $\underset{n=42)}{N(\%)}$ & Organisations' references & Coding examples \\
\hline & & & $\begin{array}{l}\text { (2012:3); WHO (2006:48); WB } \\
\text { (2003b:28-40) - APEC } \\
\text { (2010b:69); CoL (2006:2); EU } \\
\text { (2007a:30); PIF (2009:13); } \\
\text { OECS (2002:157) - AFDB } \\
\text { (2004:15); ADB (2009:71) - } \\
\text { EuropeAid (2010c:9); GIZ } \\
\text { (2012a:11); USAID (2006:1); El } \\
\text { (2009:12) }\end{array}$ & $\begin{array}{l}\text { expressed as a basic curriculum } \\
\text { principle; tutor and facilitator; }\end{array}$ \\
\hline & $\begin{array}{l}\text { new role for } \\
\text { schools }\end{array}$ & 11 & $\begin{array}{l}\text { OECD (1996:113); WB } \\
\text { (2003b:28) - EU (2007a:30); } \\
\text { CARICOM (2009:15); OECS } \\
\text { (2001:8) - USAID (2007:7); }\end{array}$ & $\begin{array}{l}\text { the important role that schools could } \\
\text { and should play in supporting } \\
\text { teachers' lifelong learning; }\end{array}$ \\
\hline
\end{tabular}

